\title{
Institutions and the Efficiency of the European Union Product Market with an Emphasis on Croatia - Dynamic Panel Data Analysis
}

\author{
Lucija Rogić Dumančić * \\ Željko Bogdan* \\ Irena Raguž Krištić *
}

\begin{abstract}
The positive relationship between product market efficiency (PME) and productivity has been established in the existing literature. An important component of productivity is the $P M E$, which is significantly affected by the quality of institutions. Weaker quality of institutions, higher levels of corruption and lower efficiency of product markets have been confirmed in countries that share similar characteristics with Croatia. The results show a positive relationship between the quality of institutions and PME while the link between corruption control and PME is negative. Exports and taxes were also significantly correlated with PME. The text additionally comments on the direction of this connection. The link between PME, institutional quality and corruption is particularly commented on in the context of Croatia and Slovenia as these are two areas that share a common past of approximately 500 years. To improve the PME, a prerequisite for greater productivity and consequently economic growth, it is necessary to change the institutional framework.
\end{abstract}

Keywords: quality of institutions; product market efficiency; global competitiveness index; panel analysis

JEL Classification: $\mathrm{E} 02, \mathrm{O} 43$

\section{Introduction}

In the literature on economic growth, much interest is paid to factors of production and technological progress (and consequently to research and development), and too

* Lucija Rogić Dumančić, Željko Bogdan and Irena Raguž Krištić are at Faculty of Economics and Business Zagreb, Trg J. F. Kennedy 6, 10000 Zagreb, Croatia. 
little to efficiency. However, it is generally known from growth theory that the level of productivity has a much stronger role played by efficiency than technology. Nevertheless, factors of production, technology and efficiency play a significant role in economic activity, so they are recognized in the Global Competitiveness Index (GCI) as important factors in the competitiveness of national economies. This index is constructed by the World Economic Forum and identifies 12 pillars of competitiveness as shown in Table 1. The grouping of competitiveness pillars corresponds to the way of defining the aggregate production function $(\mathrm{Y}=\mathrm{F}(\mathrm{K}, \mathrm{N}, \mathrm{A})$ where capital $\mathrm{K}$ and labor $\mathrm{N}$ are factors of production, and $\mathrm{A}$ denotes both efficiency and technological level), and the same is true after 2018, regardless of changing the methodology and evaluating the pillars of competitiveness. The results in the individual pillars of competitiveness are also reflected in the total value of the GCI. By comparing the values of this index, starting from the highest, the ranks of countries are determined.

Table 1: The competitiveness pillars according to the Global Competitiveness Index

\begin{tabular}{|c|c|c|c|c|}
\hline \multicolumn{5}{|c|}{ Global competitiveness index (GCI index) } \\
\hline \multicolumn{5}{|c|}{ Previous Methodology: (issues: 2006/7-2017/18) } \\
\hline Basic requirement & \multicolumn{2}{|c|}{ Efficiency Enhancers } & \multicolumn{2}{|c|}{ Innovation and sophistication factors } \\
\hline $\begin{array}{l}\text { - Institutions } \\
\text { - Infrastructure } \\
\text { - Macroeconomic environment } \\
\text { - Health and primary education }\end{array}$ & \multicolumn{2}{|c|}{$\begin{array}{l}\text { - High education and training } \\
\text { - Goods market efficiency } \\
\text { - Labor market efficiency } \\
\text { - Financial market development } \\
\text { - Technological readiness } \\
\text { - Market size }\end{array}$} & \multicolumn{2}{|c|}{$\begin{array}{l}\text { - Business sophistication } \\
\text { - Innovations }\end{array}$} \\
\hline \multicolumn{5}{|c|}{ Revised methodology - 2018/9-2020-21 } \\
\hline Enabling environment & Human capital & & Markets & Innovation ecosystem \\
\hline $\begin{array}{l}\text { - Institutions } \\
\text { - Infrastructure } \\
\text { - ICT adoption } \\
\text { - Macroeconomic stability }\end{array}$ & $\begin{array}{l}\text { - Health } \\
\text { - Skills }\end{array}$ & $\begin{array}{l}\text { - } \text { Proc } \\
\text { - Lab } \\
\text { - Fina } \\
\text { - Mar }\end{array}$ & $\begin{array}{l}\text { ct market } \\
\text { market } \\
\text { cial system } \\
\text { t size }\end{array}$ & $\begin{array}{l}\text { - Business dynamism } \\
\text { - Innovation capability }\end{array}$ \\
\hline
\end{tabular}

Source: Schwab(ed.) $(2017,2018)$.

Figure 1: GCI values and ranks for the EU member states

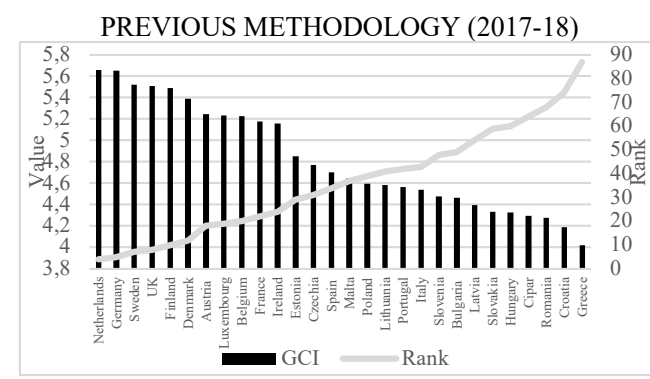
NEW METHODOLOGY (4.0) (2018-19)

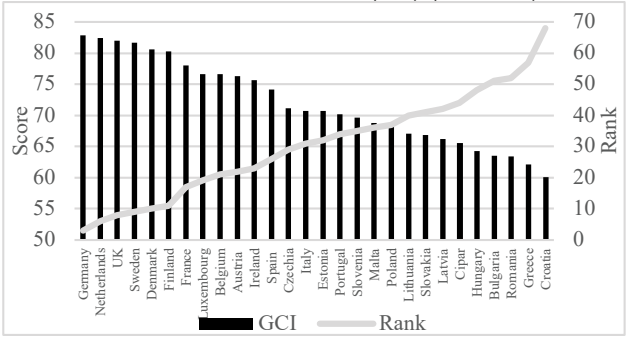

Source: Authors. 
The left graph in Figure 1 shows the values of the total GCI and the overall ranking of the EU member states (with the United Kingdom) according to the 2017/18 edition starting from the best EU economy. The Netherlands had the best position, and Croatia and Greece the worst. However, the best EU score (5.6) is significantly weaker than the theoretically best possible result (7). The right chart starts from the changed methodology for 2018, but the basic conclusion remains unchanged - 11 old EU members have the best GCI values.

If Mediterranean countries are excluded from the old EU Member States (EU-15), the new EU Member States have significantly lower GCI levels compared to the EU15. This means that there are certainly differences in post-socialist and Mediterranean countries when considering the competitiveness of EU economies. They can be largely attributed to efficiency factors, and the lower quality of institutions is imposed as the first factor of lower efficiency. In addition to impaired efficiency, weak institutions (according to growth theory) also reflect on economic activity through other components of the production function. In this paper, efficiency is viewed in part since we focus on the product market (goods market efficiency in the previous GCI methodology), but labor market efficiency and education as well as financial development are also important components of efficiency (see Efficiency enhancers group in Table 1). Furthermore, poorer quality of institutions is usually associated with higher levels of corruption. We assume a possible link between the efficiency of the product market, the quality of institutions and corruption through these hypotheses:

H1: There are significant differences among EU members: smaller EU member ${ }^{\text {, }}$ Mediterranean countries and post socialist economies stand out with poorer quality institutions, poorer product market efficiency, and higher levels of corruption;

$\mathrm{H}$ 2: Reduced efficiency of product markets in EU member states may be associated with poorer quality of institutions and higher levels of corruption.

In the empirical part, we failed to reject any of these hypotheses. These results are an important contribution of this paper since in the empirical literature, the impact of institutional quality on market efficiency is often neglected, so research is rare. Therefore, the aim of this article was to partially fill this gap on the sample of EU members.

The structure of the paper is the following. Next part presents the literature review. Third section contains empirical analysis. Fourth section comments the results with a special focus on Croatia. The fifth section presents concluding remarks.

\section{Literature review}

Problems related to economic activity and the dynamics of the product market are a matter of extensive research and economic interest. The consequence is a multitude of theoretical and empirical papers linking economic activity and product market reforms that contribute to its better efficiency. 
A theoretical analysis of product market reforms suggests that product market deregulation lowers prices, increases real wages, and reduces unemployment if it facilitates the entry of new firms (Blanchard and Giavazzi, 2003). It increases competition and reduces mark-ups (Arnone and Scalise, 2005), reduces inefficiencies and makes the price stability policy more desirable (Cacciatore, Fiori and Ghironi, 2015). However, the theory also suggests that short-term and long-term effects of these policies differ depending on how and when the policy is implemented. Deregulation reforms can be recessive in the short term and expansive in the long run. Most of the conclusions of the empirical literature, however, confirm the benefits that product market deregulation ensures to an economy such as the positive impact of competitiveness on productivity (Arnold, Nicoletti and Scarpetta, 2011; Bourlés et al., 2013; Correa-López and Doménech, 2014), economic growth (Allegra, Forni, Grillo and Magnani, 2004) and decrease in the relative prices (Bouis, Duval and Eugster, 2016); as well as a positive effect of deregulation on investments (Ardagna, Nicoletti and Schiantarelli, 2005). The empirical literature finds no negative effects in the short term even in the unfavorable macroeconomic conditions.

The direction of the link in the presented studies is from product market reforms to economic activity. However, empirical research on product market efficiency factors (including the quality of institutions) is relatively scarce. To the best of our knowledge, we were able to single out only one (relatively older) article by Adkins, Moomaw and Savvides (2002). This paper analyzes the market inefficiency as a distance from the production frontier and shows that institutions that promote more freedom in the market reduce inefficiencies. It also turns out that one of the mechanisms through which economic freedom works is greater efficiency rather than progress in knowledge.

Although empirical papers do not investigate the direct impact of institutions on efficiency, some authors theoretically and empirically investigate the impact of institutions on economic activity. The theory of growth and development does not look at the quality of institutions as a separate factor of production, but this impact is reflected in the accumulation of factors of production and/or productivity. Although Égert (2016) states that there is surprisingly little empirical research on the impact of institutions on the aggregate economic level, most of them show a positive impact of institution quality on overall productivity and economic activity (Chanda and Dalgaard, 2008; Rodrik et al., 2004; Égert, 2016; Gouveia, Santos and Gonçalves, 2017; Rodríguez-Pose et al., 2020). However, articles on the direct impact of institutions on productivity and economic activity neglect the impact on market efficiency. But according to the theory of growth and development, lower efficiency predominantly explains lower productivity rather than the technological gap (Weil, 2009). Therefore, it makes sense to assume that the poorer quality of institutions is reflected in poorer efficiency and thus the efficiency of the product market. Papers Chanda and Dalgaard (2008), Égert (2016), Gouveia, Santos and Gonçalves (2017) and Rodríguez-Pose et 
al. (2020) openly point out that better quality of institutions is reflected in better efficiency. Pattnaik and Choe (2007), on the other hand, find that performance of subsidiaries is not impacted by the quality of institutions of the country they are located in. This finding corresponds to the one by Chacar, Newburry and Vissa (2010) who find on a sample of 33 countries over a 10 -year period that institutional quality impacts only domestic firms. Likewise, Agostino et al. (2020) find that better local institutions help small and medium-sized companies of the EU become more productive (in terms of their TFP).

The efforts of these and other authors have yielded a multitude of papers, most of which confirm the positive impact of better institutions on productivity, implicitly or explicitly assumed through more efficient markets. Additionally, however, we must consider that there are also potential special characteristics of small countries, Mediterranean countries, and former socialist countries that shape institutional framework, and hence its impact on product market efficiency and consequently economic activity in a specific way. For example, smaller countries appear to be more prone to clientelism by eliminating the need for brokers and enhancing the power of clients versus patrons which degrades the institutional quality (Veenendaal, 2019). Additionally, by defining small countries as those with a population of a 5 milion or less, Bräutigam and Woolcock (2001) find that institutions of small countries develop differently from those of large countries due to greater aid and trade dependence as well as more vulnerability to external shocks. However, although they do not consider that there is a significant difference in the quality of institutions between small and large countries, they find that the quality of small country institutions is even more important than those in large countries because of their vulnerability (Bräutigam and Woolcock, 2001). As far as the affiliation to the Mediterranean group of countries is concerned, these countries share geographical and many cultural pecularities, which stand in contrast with other countries of the EU. These range in the literature from simple differences such as the different understandings of honour (Mosquera, Manstead and Fischer, 2002) to "an internal cohesiveness in moral-cognitive terms" of the Mediterranean basin (Gilmore, 1987). And although many antropologists disagree with a notion of a "Mediterranean cultural unity" (de Pina-Cabral, 1989), we believe that the existing similarities of this group of countries might have had a specific way of impacting institutional development and consequently economic activity. Finally, it is expcted that the post-socialist group of countries, by sharing a common history, also display some common institutional characteristics. It makes sense to assume that some of them were formed well before the establishment of the communist regime after World War $\mathrm{II}^{2}$. These institutional differences in the sets of countries were the basis for the construction of the first hypothesis.

Finally, the findings of the empirical literature in this review, as well as the above-mentioned considerations of specific characteristics that might play a role in the functioning of institutions of different countries, make us suspect that the poor 
quality of institutions is one of the main explanations for low product market efficiency (and consequently poor economic performance). Therefore, the first step in empirical analysis must be to find a suitable indicator of product market efficiency which is the goal of the next part of this paper.

\section{Empirical analysis}

\section{Definition of variables, data and expected signs}

At the beginning of this paper, the GCI is described, including both methodologies. According to the old methodology, the values of this index range between 0 and 7 , with the increase of the index reflecting the improved competitiveness of the economy. With the new methodology, the names of the pillars of competitiveness and their grouping have been changed (Table 1), but the values of the index have also been transformed, which now range from 0 to 100. Given the longer annual series, for this paper the data from the old methodology is more important since we have 11 observations by country. We use annual data for all of the EU countries from 2008 until 2018 giving a total of 308 observations. This data period is constrained by the availability of the appropriate data.

The dependent variable in this model is the GCI value for the sixth pillar - product market efficiency (variable PME). The importance of PME for the global productivity of the national economy is described in this quote from (Schwab(ed.), 2017): "Countries with efficient goods markets are well positioned to produce the right mix of products and services given their particular supply-and-demand conditions, as well as to ensure that these goods can be most effectively traded in the economy. Healthy market competition, both domestic and foreign, is important in driving market efficiency, and thus business productivity, by ensuring that the most efficient firms, producing goods demanded by the market, are those that thrive. Market efficiency also depends on demand conditions such as customer orientation and buyer sophistication. For cultural or historical reasons, customers may be more demanding in some countries than in others. This can create an important competitive advantage, as it forces companies to be more innovative and customer-oriented and thus imposes the discipline necessary for efficiency to be achieved in the market".

Another important factor in the efficiency of the product market is the quality of institutions (variable INST). North (1990) defines institutions as the rules of the game in a society, or as limits set by humans in order to shape human interactions. For economic relations important economic institutions are those such as property rights, functioning markets, contracts and exchange mechanisms. The institutions enhance market efficiency by addressing the market failures, ensuring an availability of information and thus enabling the prices to be the correct signals coming from the 
markets (Gilson and Kraakman, 2003). The values of this indicator are also taken from the GCI (pillar Institutions).

Since our analysis covers a short period of only 11 years, our model specification is limited with a number of explanatory variables. The total number of variables applied in the empirical analysis is limited to five, and their list, source and expected signs are listed in Table 2.

Table 2: Data description and sources

\begin{tabular}{|c|c|c|c|c|}
\hline Variable & Label & Measure & Source & $\begin{array}{c}\text { The expected } \\
\text { sign }\end{array}$ \\
\hline$P M E$ & $\begin{array}{c}\text { Product } \\
\text { market } \\
\text { efficiency }\end{array}$ & $\begin{array}{c}\text { Greater index indicates more efficient product } \\
\text { markets. Weighted average of current and } \\
\text { previous year. }\end{array}$ & WEF database & $\begin{array}{c}\text { Dependent } \\
\text { variable }\end{array}$ \\
\hline INST & Institutions & $\begin{array}{c}\text { Index, [1,7]. } \\
\text { Greater index indicates higher quality of } \\
\text { institutions. Weighted average of current and } \\
\text { previous year. }\end{array}$ & WEF database & + \\
\hline EXP & Exports & $\begin{array}{c}\text { Exports as a percentage of GDP (Constant, } \\
\text { 2010) }\end{array}$ & WDI database & + \\
\hline CORRUPT & $\begin{array}{c}\text { Control of } \\
\text { corruption }\end{array}$ & $\begin{array}{c}\text { Index, [-2.5, 2.5]. } \\
\text { Gorruption. Weighted average of current and } \\
\text { previous year. }\end{array}$ & $\begin{array}{c}\text { Kaufman, Kraay and } \\
\text { Mastruzzi (2010) }\end{array}$ & + \\
\hline TAX & Tax burden & Tax revenue as a percentage of GDP & WDI database & $+/+$ \\
\hline
\end{tabular}

Source: Authors

The variables PME, INST and CORRUPTION are interrelated. Better quality of institutions is associated with greater confidence in the political and judicial system, as well as with policies that encourage competition and a better business environment. Therefore, the good quality of institutions is reflected in lower levels of corruption and better efficiency of the product market. This improves overall economic activity, which in turn can affect the quality of government, and thus INST and CORRUPTION. So, a bidirectional link among these variables is possible.

The link between EXP and PME can be sought through the relationship between productivity and exports. It is not entirely clear from economic theory whether productivity improvement precedes exports (via price competitiveness) or exports lead to better productivity. Efficiency is a "part" of productivity and, therefore, the two-way link between EXP and PME is self-evident. EXP can also be a proxy variable for openness, and just improved efficiency is one of the channels through which openness has a positive impact on economic growth (Weil, 2009). Instead of exports, we could include imports or FDI, but we took a variable that we consider a better indicator of competitiveness. 
It is also known from the economic literature that a higher tax burden (variable TAX) implies worsened efficiency, so a negative relationship should be expected (Weil, 2009). However, countries with a higher degree of product market efficiency are also countries with a higher level of income that also allows them higher tax revenues. The correlation between TAX and PME in this case may also be positive, but it is more likely to go from PME to TAX. We will not opt in advance for the expected sign.

The choice of all variables was taken from (Rogić Dumančić, Bogdan and RagužKrištić, 2021) and proving the first hypothesis requires an identical partition of the sample into subsamples ${ }^{3}$. For each of these subsamples, arithmetic means were calculated separately in Table 3 (Appendix) and an arithmetic mean difference test was performed. Although the first hypothesis was strictly set for the variables PME, INST, and CORRUPT, this test was performed for each variable. The z-score (column 11) was mostly negative signaling lower averages for small states, Mediterranean countries, post-socialist economies and Croatia. The only exceptions are the positive differences for EXP and TAX in small countries. But a statistically significant difference was confirmed for all variables except for TAX. The only exceptions are post-socialist countries where there is no statistically significant difference in averages for the EXP variable while it exists in the case of the TAX variable. These results could have been influenced by the inclusion of Croatia in small, Mediterranean and post-socialist economies since it is still the country with the worst performances. But the exclusion of Croatia (Table 4 - Appendix) did not significantly change the conclusions, except that the difference in arithmetic means for the variables PME and INST in small countries became insignificant. Consequently, we are not able to reject the first hypothesis.

\section{Empirical model and results}

However, the presented analysis does not reveal the relationship between the studied variables, but it can be revealed by estimating the econometric model. The small length of annual data required the application of panel analysis and even the inclusion of old EU members (EU-15) in the sample. Due to the relatively small T, it makes sense to estimate the static panel model:

$$
y=\bar{\alpha}+x \beta+\alpha+\varepsilon
$$

$y=\left[y_{i t}\right]$ denotes the efficiency indicator vector (variable PME). $x\left[I N S T_{i t} E X P_{i t}\right.$ $\left.C O R R U P T_{i t} T A X_{i t}\right]=$ is the matrix of independent variables (explained above) and $\beta$ is a vector of regression coefficients. $\alpha=\left[\alpha_{i t}\right]$ is individual heterogeneity and $\varepsilon$ $=\left[\varepsilon_{i t}\right]$ is random variable. However, one issue remained unresolved by applying this estimation. The dependent variable is characterized by path dependence and, therefore, the lag of the dependent variable $(\mathrm{y}(-1))$ should be included as a regressor 
leading to correlation with $\alpha$ and endogeneity. Namely, in this case model (1) takes the form (dynamic panel model):

$$
y=\gamma y(-1)+\bar{\alpha}+x \beta+\alpha+\varepsilon .
$$

If the correlation between $\mathrm{y}(-1)$ and $\alpha$ is ignored, OLS estimators would be biased and inconsistent. Therefore, when estimating the parameters of a dynamic panel model, there are different estimators whose suitability varies depending on the sizes of the spatial and time component of the model. Equation (2) implicitly assumes strictly exogenous regressors, so LSDV estimator and corrected LSDV estimator (LSDVC) are possible options. The poor properties of the LSDV estimator ruled it out as an adequate choice, but the relatively small variance (and thus efficiency) made it the basis for the construction of Kiviet (1995) LSDVC estimator. Based on the previous section, however, we conclude that our variables are most likely not strictly exogenous. In such circumstances, an LSDVC estimator would not be the optimal choice, so it is necessary to apply estimators that allow for potential endogeneity in the model i.d. (Anderson and Hsiao, 1981, 1983 - hence AH), difference GMM (Arellano and Bond, 1991 - hence AB) or a system GMM estimator (Arellano and Bover, 1995; Blundell and Bond, 1998 - hence BB). The choice of the appropriate estimator depends on the suitability for the panel model with a small-time dimension $(\mathrm{T}=$ 10). Some simulations (Judson and Owen, 1999; Buddelmeyer, Jensen, Oğuzoğlu and Webster, 2008) allow the use of LSDVC, AH or difference GMM estimators. Their common conclusion is that, according to the bias assessment, LSDVC is the best estimator if the dependent variable is weakly persistent, and that an OLS estimator (small T and N) or GMM / AH estimator can be used for persistent series. The simulation Škrabić Perić (2019) is best adapted to the size of our sample $(\mathrm{N}=30, \mathrm{~T}=10)$ and shows that in the case when $\mathrm{N}=30, \mathrm{~T}=10$ LSDVC produces the smallest bias for $\gamma$ when $\gamma=0.2$, while for moderately and highly persistent dependent variable BB shows the least bias. For $\beta, \mathrm{AB}$ estimator produces the smallest bias in more than half of designs. When RMSE is observed, the LSDVC estimator is the most effective in almost all combinations. Therefore, the results of this study can be interpreted in favor of LSDVC but also both GMM estimators. We will base our conclusions on both the difference GMM and the LSDVC estimator.

Difference GMM starts from the differentiation of equation (2) to exclude individual heterogeneity. After model transformation the regression variables (now the first differences) were correlated with the residuals. Since it is known that the OLS estimators would be biased and inconsistent, it is important to include instrumental variables that are well correlated with the first differences, but not with the residuals, although they will not be formal regressors. The lagged values of the untransformed variables are the first candidates for the instrumental variables, but the lagged values that come later in the future will have less significance and will not be good instru- 
ments. Therefore, too many (as well as too few instruments) can degrade the quality of the model (Roodman, 2009). The validity of the instruments is tested using the (Sargan, 1958) test which is quite sensitive so it can lead us to the wrong conclusion. Kiviet (2020) recommends accepting the null hypothesis in the Sargan test if the p-value is at least between 0.1 and 0.2. Based on additional proposals (Kiviet, 2020), a model estimating 6 parameters (our basic model) should have approximately 10 to 30 instruments.

Another important property relates to the absence of autocorrelation. The instrument will not be correlated with the residual only if there is no autocorrelation in the residuals. Due to the regressors in the first differences, the absence of autocorrelation of the second and higher orders is required (Arellano and Bond (1991) or AB test). Moreover, first-order autocorrelation is necessary since its absence could also mean poor model specification. Kiviet (2020) recommends that the first-order autocorrelation be accepted, and that in the Arellano-Bond second-order autocorrelation test the null hypothesis be accepted with a p-value at least between 0.05 and 0.15 . Thus, it can be roughly said that the p-values for both the second-order autocorrelation and for the Sargan test should be at least about 0.2 so that we can be relatively sure that the model is acceptable.

A third important property for valid instruments is the absence of a unit root since model estimation simulations are created assuming stationary series ${ }^{4}$.

Special applications have been created that can perform GMM estimation with a significantly reduced number of instruments. One of them (xtdpdgm recommended by Kripfganz, 2019) is applied in this article as well. Of course, the set limits on the instruments are also reflected in the results, so the total number of estimated regressions is equal to 35 . Clearly, not all of them can be presented in this text, so a few will be singled out and the conclusions of the remaining ones will be outlined. A table with estimates of the panel model is left for appendices (table 5).

The selection of regressions for Table 5 was derived from the Andrews - Lu criterion (Andrews and Lu, 2001) - the first 11 regressions with the lowest value of the BIC criterion were taken. The reason for such a large number of regressions stems from the fact that the lower values of this criterion do not simultaneously reflect the recommendations of Kiviet (2020) and Kripfganz (2019). They also suggest that even dummy variables for individual years should never be neglected. In such a case, the number of parameters would increase (in our sample to 15) and thus the number of instruments (minimum 19 and the maximum limit is between 29 and 44). The BIC criterion is the smallest in regression with time effects, but the number of instruments is also the largest - 50 (GMM 1). In other estimated regressions, the number of instruments decreased but remained higher than 30 , so only in the 10th regression is the acceptable 29, and in the 11th regression even better $25^{5}$. Due to the smallest number of instruments, the last regression was extended with time effects (GMM 12), but in such a model, first-order autocorrelation was not confirmed, so the model is not suitable. In both the first and last regression, the time effects are statistically significant (last row of Table 5), but the last model is not appropriate. 
Regardless of the number of instruments, all estimated and shown regressions lead to a similar conclusion: there is a positive and statistically significant relationship of the PME variable with the INST, EXP and TAX regressors, while the relationship with CORRUPT is negative but not significant when time effects are included. The variables EXP and TAX are also significant but this will be commented on later. There is a significant change in the model with the inclusion of time effects since there is a significant increase in the parameter with the variable INST, but also a significant decrease in the coefficient with the lag of the dependent variable. Such a result could suggest the possibility that the shock in the INST variable could contribute to a significant short-term effect on PME that could disappear more rapidly over time. However, due to a large number of parameters, time effects were not monitored in all regressions. Although Kiviet (2019) and Kripfganz (2020) recommend the inclusion of time effects, from the penultimate and last column of Table 5 we notice that this may also worsen the model.

The results presented in Table 5, however, do not sufficiently reveal their robustness since they present approximately one-third of the estimated regressions. In the twelve estimated regressions, all variables were significant and most of them were already presented in Table 5 (two versions of 21 and 17 instruments were omitted). In the next five regressions (14\%), the significant variables are INST and CORRUPT. One of these variables is significant in eight cases or $23 \%$ while none of them is significant in seven regressions or $20 \%$. Finally, we also have 3 regressions in which there is only a significant time lag of the dependent variable (9\%). Most of these regressions are omitted from Table 5 for the following reasons:

1. Higher values of MSN criteria (BIS) than those shown in the table;

2. Diagnostic problems. Some of them did not pass the autocorrelation test, which is a sign of misspecification. Most also have p-values of the Sargan test at the limit recommended by Kiviet (ranging mostly from 0.12 to 0.15 ), but this does not mean that the model is completely unusable (see Kiviet (2020) comments);

3. Additional regressions would increase the already large dimensions of the article. If we exclude the ARDL specification (since it also contains time lags of regression variables - $14 \%$ of all regressions), individual variables can also be commented on:

1. The variable INST had a negative sign in only 3 cases, and was statistically significant in 19 cases $(54 \%)$;

2. The variable CORRUPT had a positive sign in only 2 cases, and was statistically significant in 14 cases $(40 \%)$. This result is quite surprising for two reasons: primarily this is not detected in the static panel model ${ }^{6}$ (except in the case of the first difference estimator) since the parameter is positive but insignificant; second, it also implies that a higher degree of corruption contributes to better product market efficiency, which is contrary to our expectations. However, the correlation matrix shows an almost perfect positive partial correlation between the variables PME, INST, and CORRUPT. Clearly, it cannot detect which correlation is direct 
and which through another variable - e.g., the INST variable could also "trigger" a correlation between PME and CORRUPT. The introduction of the time lag of the dependent variable as a regressor certainly emphasized the degree of multicollinearity that contributed to the erroneous sign of the CORRUPT variable;

3. The variable EXP had a negative sign in 6 cases, but was statistically significant in 18 cases (or 51\%). But in all cases the sign of the parameter was very close to zero. Such a result suggests the possibility that a correlation between PME and EXP should rather be sought in the opposite direction, but this is not the subject of this paper;

4. For the TAX variable, the parameter was negative only once, and the significance was confirmed in 25 regressions (71\%). The significance of this variable is the most probable, but also the magnitude of its parameter varies the least (according to the coefficient of variation which is about 52\%). The sign and parameter size of this variable also suggests the possibility that causality could go from PME to TAX which is not explored in this paper.

From all the above, it can be concluded that we have presented the best and most appropriate results in Table 5, but that the relationship still cannot be considered robust ${ }^{8}$.

Although robustness has not been confirmed, these results can be related to the first hypothesis. They show that poorer quality of institutions is associated with lower efficiency of product markets. According to the first hypothesis, the quality of institutions is significantly lower in small economies, Mediterranean economies, post-socialist economies and Croatia compared to the rest of the EU. According to these results, these groups of countries should also achieve a lower levels of product market efficiency, as suggested by Tables 3, 4 and 5 (Appendix). The last part of Table 3 also leads to the conclusion that the quality of institutions and the efficiency of the product market should be the weakest in Croatia. Therefore, the obtained results should be interpreted in the context of Croatia in the next session.

\section{Comments of results with a special focus on Croatia}

The results of the previous analysis can be applied to Croatia - the poor quality of institutions in Croatia also has an adverse effect on the efficiency of the product market. Nevertheless, research on the economic consequences of this historically poor quality of institutions in Croatia is rare, but several papers can be singled out: Franičević and Bićanić (2007), Ivanković (2017) and Kotarski and Petak (2019). All of these selected papers emphasize the negative consequences of poor institutional quality in Croatia, focusing mainly on clientelism, and show its disastrous effects on economic growth. We have expanded the existing empirical analyzes with the intention to determine the impact that institutions have on the efficiency of the product market in Croatia. Therefore, we ask the question: which components of institutions are particularly bad 
and adversely affect the competitiveness of Croatia. Historical, geographical, cultural, demographic and economic reasons justify comparing the quality indicators of institutions in Croatia with the same indicators in Slovenia.

All presented figures 2-4 in the Appendix compare the position of Croatia with Slovenia. Figure 2 shows the ranks of subcomponents within the Institutions and Product market efficiency for Croatia and Slovenia according to the older GCI methodology (2017-18) while Figure 3 shows identical components according to the to the latest methodology (GCI 2018-19). The analysis of institutions in Figure 2 shows that Croatia has a rank of 100 and worse in almost $60 \%$ of components, while in only three cases it achieves a position more favorable than 50th place (poor results even in the global context). In comparison, Slovenia's position in the same subcomponents in approximately $50 \%$ of cases is between 50th and 100th place. The second chart of Figure 2 shows the positions of Croatia and Slovenia in the efficiency of the product market. While Slovenia achieves a better result than 50th place in more than a half of the subcomponents, Croatia generally achieves a placement below 80th place. According to the latest methodology (GCI 2018-19), Slovenia also shows much better results in these components than Croatia (Figure 3 ).

The quality of the institutional framework is also reflected in the ease of doing business. The attitudes of entrepreneurs regarding this are presented in Figure 4 but the structure of responses differs. Common to both countries is inefficient government bureaucracy as one of the five main problems faced by entrepreneurs. It often appears to be the most important in Croatia, while in Slovenia its importance has increased in the context of the recent crisis, although it has also been important before. Between 2009 and 2015, Slovenian entrepreneurs highlighted access to finance as the main problem. In 2016 and 2017, tax rates and inefficient government bureaucracy became their main problems. Similarities between Croatia and Slovenia also exist in the fact that their entrepreneurs do not consider crime and fraud, inadequate supply of infrastructure, foreign currency legislations, inflation as problematic factors in doing business.

Although nowhere (not even in Slovenia) are the institutions perfect, the somewhat greater importance that Croatian entrepreneurs attach to inefficient government bureaucracy (2017 21\% vs. 16.5\% in Slovenia), corruption (2017 11.5\% vs. 5.4\% in Slovenia) and policy instability (2017 $13.4 \%$ vs. $8.4 \%$ in Slovenia) clearly shows how the poor the quality of institutions makes it difficult to do business in Croatia and thus contributes to lower efficiency of the product market.

\section{Conclusions}

This paper aimed to test if there is a positive impact of the quality of institutions on the product market efficiency in the EU. The text is based on testing two hypothe- 
ses: first, that smaller EU members, the Mediterranean, and post-socialist economies have poorer quality institutions, poorer product market efficiency, and higher levels of corruption; and second, that poorer quality of institutions and higher levels of corruption may be associated with reduced product market efficiency in EU member states. The first hypothesis was proved by testing the equality of arithmetic means, while dynamic panel analysis was applied to prove the second hypothesis.

When testing the dynamic panel analysis, it was necessary to select the appropriate regression variables, which were the quality of the institution, the level of corruption, exports, and tax revenues. We expect that greater freedom from corruption and better quality of institutions contribute to improving the efficiency of the product market. Only in the case of tax revenues we have not decided in advance on the expected sign of the correlation, while in the case of exports a positive correlation is expected. We did not assume strictly exogenous regressors which allowed the application of the GMM in the estimation of the regression model. The results depend on the number of instrumental variables. However, most of them point to a positive link between the quality of institutions and the efficiency of the product market. The parameter with corruption control is negative which is most likely due to multicollinearity. We expected a negative parameter, but with the GMM estimator this is achieved only when the variable INST is excluded from the model. In most cases, the significance of the tax revenues has been confirmed, and the sign of the connection is positive. Exports are significant in half of the cases, but all parameters are very close to zero. The results for the last two variables suggest the possibility that causality is more appropriate to look for in the opposite direction but this has not been tested here.

The obtained results are especially commented in the context of Croatia and Slovenia. The quality of the institutional framework and the efficiency of the product market are at a lower level in Croatia compared to Slovenia. Institutions certainly shape the degree of difficulty of doing business in both countries. It is indicative that Croatian entrepreneurs attach more importance to inefficient state bureaucracy, corruption, and policy instability than Slovenian ones, which clearly shows how the institutional framework makes it difficult to do business in Croatia and contributes to less efficient product markets.

It should also be borne in mind that research into the factors influencing product market efficiency is extremely rare, especially in EU Member States. Therefore, no definitive answer can be expected from our research, but it represents an important contribution. In the text, we have made it clear that the obtained connections are not considered robust, so with more precise data and longer time series, future research will provide the final answer.

\section{Acknowledgment}

This paper was supported by the Croatian Science Foundation project number 6785 . 


\begin{tabular}{|c|c|c|c|c|c|c|c|c|c|c|c|c|c|c|c|c|c|c|c|c|c|c|c|c|c|}
\hline 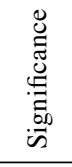 & $\sqrt{3}$ & & * & * & * & * & & 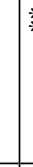 & 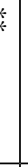 & 1 & 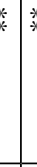 & & & $\stackrel{*}{*}$ & $*$ & & $*$ & $\%$ & & $*$ & * & & & & 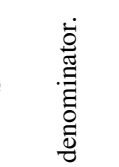 \\
\hline$\stackrel{\overrightarrow{0}}{\oplus}$ & $\exists$ & $\begin{array}{c}\stackrel{\hat{\vartheta}}{\Xi} \\
\hat{\ominus}\end{array}$ & $\left|\begin{array}{c}\tilde{y} \\
0 \\
i\end{array}\right|$ & $\begin{array}{l}\vec{t} \\
\stackrel{0}{0} \\
i \\
i\end{array}$ & 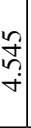 & ביב. & & & $\begin{array}{l}0 \\
2 \\
\\
\end{array}$ & & مُ & 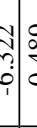 & & $\stackrel{8}{2}$ & 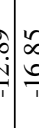 & 8 & $\frac{2}{7}$ & $\overbrace{\infty}^{\infty}$ & & \begin{tabular}{l}
0 \\
0 \\
\hdashline \\
1 \\
1
\end{tabular} & $\begin{array}{c}\tilde{\imath} \\
\stackrel{1}{1}\end{array}$ & 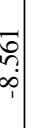 & & & 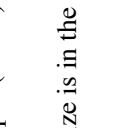 \\
\hline 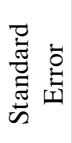 & 의 & & 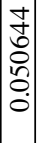 & $\begin{array}{l}\Sigma \\
\overline{0} \\
\infty \\
0 \\
0 \\
0\end{array}$ & $\begin{array}{l}\vec{N} \\
\vec{N} \\
\vec{v} \\
\dot{v}\end{array}$ & $\begin{array}{c}\infty \\
2 \\
\infty \\
\infty \\
\vdots \\
0 \\
0\end{array}$ & $\begin{array}{l}\infty \\
\\
\vdots \\
n \\
0 \\
0\end{array}$ & & $\begin{array}{l}0 \\
0 \\
0 \\
0 \\
0 \\
0 \\
0 \\
0\end{array}$ & $\begin{array}{c}5 \\
0 \\
0 \\
0 \\
0 \\
0 \\
0\end{array}$ & 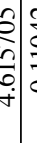 & 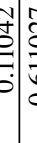 & & & 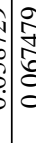 & 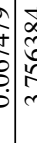 & : & فी & & 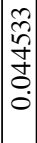 & $\begin{array}{l}1 \\
0 \\
\hat{0} \\
0 \\
0 \\
0\end{array}$ & 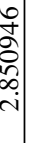 & & & 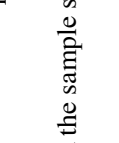 \\
\hline 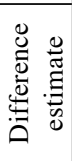 & $\hat{a}$ & $\begin{array}{l}\widehat{c} \\
\stackrel{\Xi}{=}\end{array}$ & $\begin{array}{c}0 \\
\infty \\
\infty \\
0 \\
\vdots \\
1\end{array}$ & 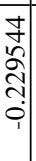 & $\begin{array}{l}\text { tे } \\
\text { ڤे } \\
\vdots \\
\dot{i}\end{array}$ & $\begin{array}{c}0 \\
2 \\
\vdots \\
\vdots \\
\vdots \\
\vdots \\
1\end{array}$ & & & \begin{tabular}{l|l} 
\pm \\
0 \\
0 \\
0 \\
0 \\
0 \\
1 \\
1
\end{tabular} & 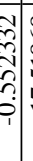 & 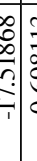 & 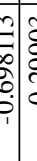 & & d & 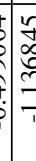 & 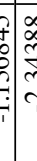 & 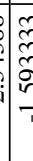 & 彳ी & & 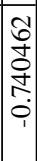 & 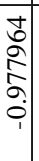 & 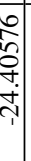 & & & 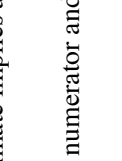 \\
\hline$\sum^{\star \pi}$ & & $\begin{array}{l}\widehat{a} \\
\stackrel{\Xi}{\Xi} \\
.\end{array}$ & $\begin{array}{c}\hat{\hat{n}} \\
\text { nิ. }\end{array}$ & $\begin{array}{c}\mathcal{N} \\
0 \\
0 \\
0\end{array}$ & $\begin{array}{l}\hat{\Xi} \\
\vec{\lambda} \\
\vec{\Delta}\end{array}$ & . & 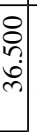 & : & กิ & $\begin{array}{l}0 \\
0 \\
0 \\
0 \\
0 \\
\end{array}$ & ה. & 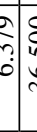 & & $=$ & $3 \frac{\alpha}{6}$ & 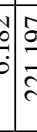 & â & 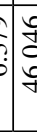 & 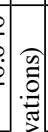 & 命 & $\begin{array}{c}\mathcal{N} \\
\stackrel{\sigma}{0} \\
0\end{array}$ & $\begin{array}{l}\hat{a} \\
\vec{\lambda} \\
\vec{a}\end{array}$ & & & 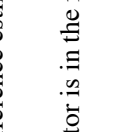 \\
\hline$\Xi$ & & $\mid$\begin{tabular}{|c|}
$\overrightarrow{0}$ \\
0 \\
0 \\
0
\end{tabular} & $\begin{array}{l}0 \\
\partial \\
\infty \\
c\end{array} \mid$ & 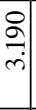 & 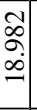 & 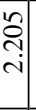 & 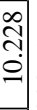 & $\begin{array}{l}0 \\
0 \\
0 \\
0 \\
0 \\
0 \\
0\end{array}$ & $\begin{array}{c}0 \\
0 \\
c \\
c \\
\end{array}$ & 2 & 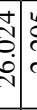 & : & S & 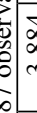 & 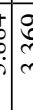 & 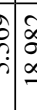 & 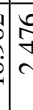 & î & $\begin{array}{l}0 \\
0 \\
0 \\
0 \\
0 \\
\vdots \\
\vdots\end{array}$ & 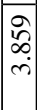 & 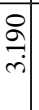 & 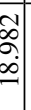 & & 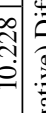 & 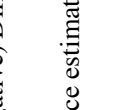 \\
\hline 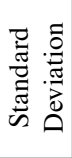 & 6 & \begin{tabular}{c}
0 \\
0 \\
0 \\
\hdashline \\
$\vdots$ \\
$\vdots$ \\
0 \\
0 \\
0
\end{tabular} & $\begin{array}{c}n \\
\\
\frac{n}{n} \\
\stackrel{5}{0} \\
0\end{array}$ & 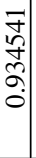 & مิ & | & 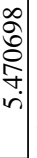 & : & . & б. & 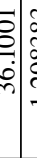 & 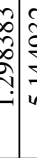 & 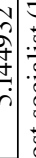 & 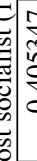 & $\begin{array}{lll}2 \\
2 \\
2\end{array}$ & 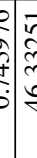 & ấ & $\begin{array}{l}\frac{2}{2} \\
\frac{1}{3} \\
\text { in }\end{array}$ & 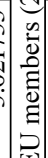 & 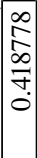 & $\begin{array}{c}\tilde{0} \\
\infty \\
\tilde{O} \\
\tilde{\sigma} \\
\infty \\
0\end{array}$ & $\begin{array}{c}\infty \\
\infty \\
0 \\
0 \\
\infty \\
m\end{array}$ & & 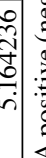 & 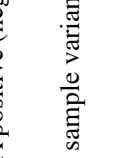 \\
\hline 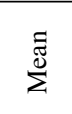 & $\sqrt{0}$ & $\Xi$ & $\frac{\partial}{7}$ & $\begin{array}{l}\vec{f} \\
\dot{f} \\
\dot{+}\end{array}$ & $\begin{array}{l}\frac{a}{\widehat{n}} \\
\stackrel{\Omega}{n}\end{array}$ & 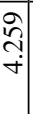 & 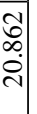 & 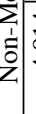 & $\begin{array}{l} \\
\\
+ \\
\dot{f}\end{array}$ & $\begin{array}{l}\stackrel{2}{\circ} \\
\dot{f}\end{array}$ & 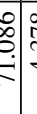 & 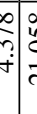 & & $\bar{z}$ & \begin{tabular}{l|l}
0 \\
0 \\
\hdashline
\end{tabular} & كُ & ?: & $\hat{\overbrace{}}$ & 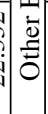 & 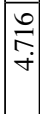 & $\begin{array}{l}m \\
\overrightarrow{0} \\
\dot{f}\end{array}$ & 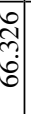 & & & $\begin{array}{l}\frac{\mathscr{J}}{3} \\
\frac{0}{0} \\
\frac{\pi}{3}\end{array}$ \\
\hline 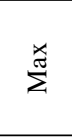 & & จิ & $\begin{array}{c}\text { जे } \\
\text { s. }\end{array}$ & 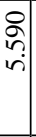 & 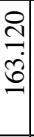 & $\begin{array}{l}\stackrel{\infty}{a} \\
\stackrel{n}{n}\end{array}$ & $\begin{array}{l}0 \\
+ \\
0 \\
\dot{0} \\
+\end{array}$ & 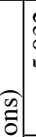 & $\begin{array}{l}\mathrm{c} \\
\mathrm{c} \\
\mathrm{n} \\
\end{array}$ & : & 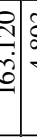 & $\begin{array}{l}0 \\
0 \\
\dot{f}\end{array}$ & & de & : & 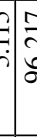 & ô & $\hat{f}$ & 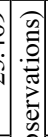 & $\stackrel{9}{\exists}$ & $\left|\begin{array}{l}\vec{d} \\
0 \\
\dot{\infty} \\
\dot{r}\end{array}\right|$ & 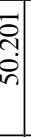 & 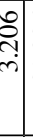 & & 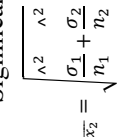 \\
\hline$\stackrel{\Xi}{\Sigma}$ & & \begin{tabular}{l|l} 
& 0 \\
2 \\
0 \\
0 \\
0 \\
0 \\
$\infty$ \\
$\infty$ \\
0
\end{tabular} & & & 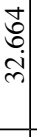 & $\begin{array}{l}\overrightarrow{0} \\
0 \\
i \\
ن\end{array}$ & 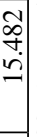 & \begin{tabular}{l|c} 
& \\
& \\
0 \\
0 \\
0 \\
0 \\
2 \\
2
\end{tabular} & $\begin{array}{c}\infty \\
\frac{\infty}{n} \\
m \\
m\end{array}$ & 'े & $\begin{array}{c}0 \\
0 \\
0 \\
0 \\
0 \\
0 \\
0\end{array}$ & 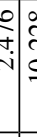 & 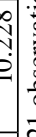 & 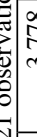 & $\therefore$ & c) & $\mid \begin{array}{l}2 \\
\vdots \\
\vdots\end{array}$ & $\begin{array}{l}\text { d } \\
\text { dे } \\
\end{array}$ & 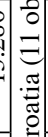 & $\begin{array}{c}\infty \\
\stackrel{\infty}{*} \\
\\
\end{array}$ & $\begin{array}{l}n \\
\tilde{f} \\
\tilde{n} \\
\tilde{n}\end{array}$ & 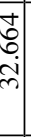 & & & $\frac{\sqrt{3}}{\sqrt{3}}$ \\
\hline 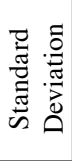 & a) & 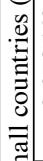 & 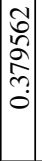 & 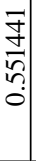 & $\begin{array}{l}\infty \\
\stackrel{\infty}{+} \\
\frac{2}{2} \\
\text { ले }\end{array}$ & $\begin{array}{l}0 \\
\hat{0} \\
0 \\
\vdots \\
0 \\
0\end{array}$ & 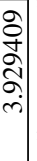 & : & 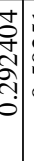 & $\begin{array}{c}5 \\
\vdots \\
\vdots \\
0 \\
0\end{array}$ & 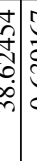 & $\begin{array}{c}6 \\
6 \\
0 \\
0\end{array}$ & 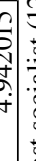 & 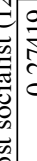 & ț & 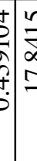 & $\begin{array}{l}1 \\
2 \\
2 \\
2 \\
0 \\
0\end{array}$ & 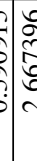 & 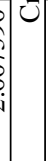 & 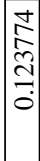 & 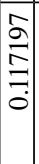 & 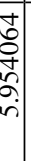 & $\begin{array}{l}m \\
\infty \\
c \\
\\
\\
0 \\
0\end{array}$ & & 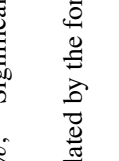 \\
\hline 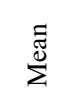 & $\theta$ & $\hat{\sim}$ & $\begin{array}{l}\bar{\sigma} \\
\dot{\sigma}\end{array}$ & $\stackrel{n}{\underset{f}{f}}$ & $\begin{array}{l}\bar{a} \\
0 \\
2 \\
2\end{array}$ & 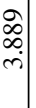 & $\begin{array}{c}\stackrel{v}{\sim} \\
\stackrel{\mathrm{N}}{2}\end{array}$ & $\Sigma$ & F্ & 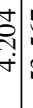 & 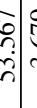 & \begin{tabular}{c}
0 \\
6 \\
$\vdots$ \\
\hdashline
\end{tabular} & & $\stackrel{2}{2}$ & 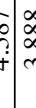 & : & co & $\mid \begin{array}{l}0 \\
0 \\
0\end{array}$ & & 号 & $\left|\begin{array}{l}\Re \\
\hat{\sigma} \\
\end{array}\right|$ & - & & & $\begin{array}{l}\overline{\tilde{J}} \\
. \cong\end{array}$ \\
\hline $\begin{array}{l}\frac{0}{0} \\
\frac{\pi}{\pi} \\
\frac{\pi}{\pi}\end{array}$ & & & $\sum_{a}^{1}$ & & 率 & ن & 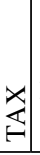 & & & & 宏 & & & & & 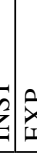 & 这 & & & & $\underline{\underline{n}}$ & & & & 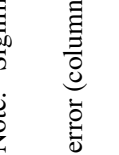 \\
\hline
\end{tabular}




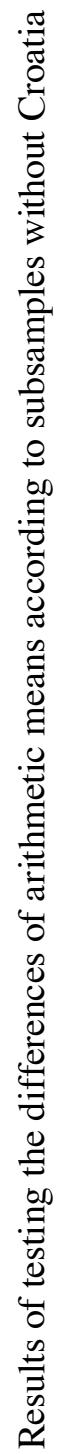

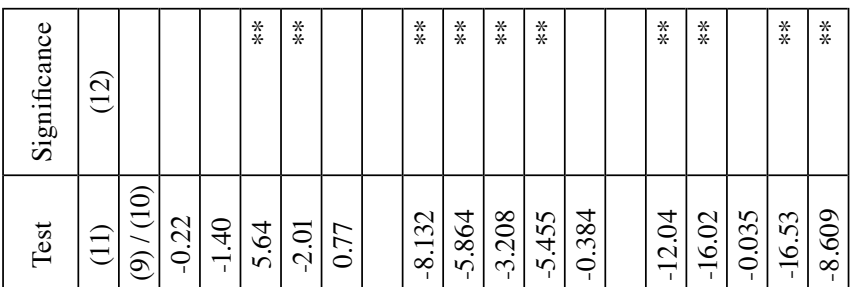

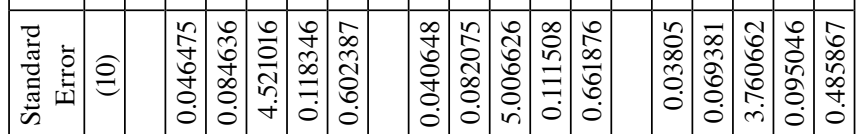

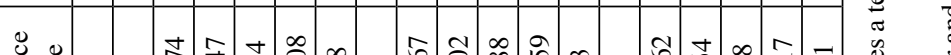

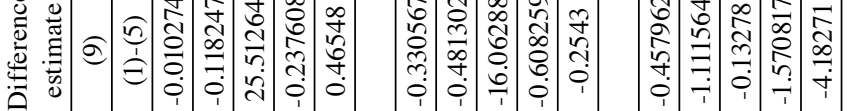

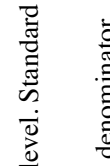

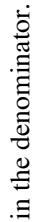

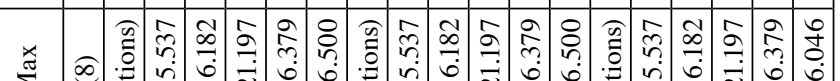

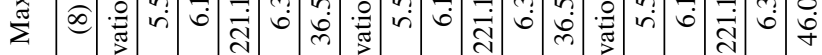

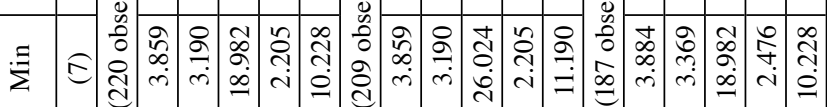

z .

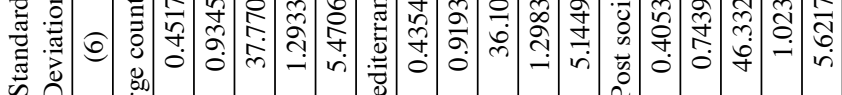
के

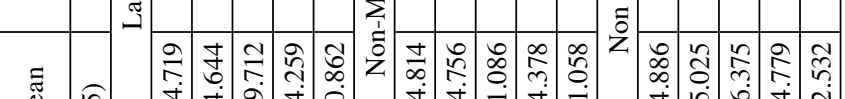

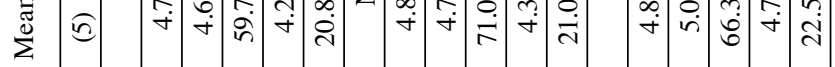

苛

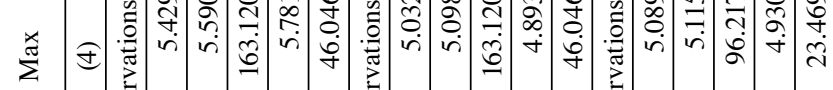

$\begin{array}{lll}< & 0 \mid \\ N & 0\end{array}$

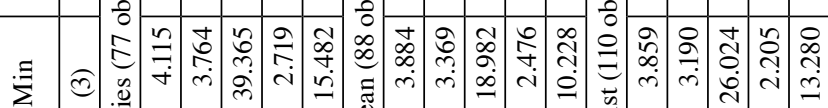

z б

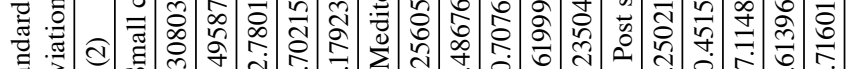

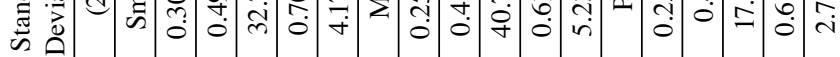

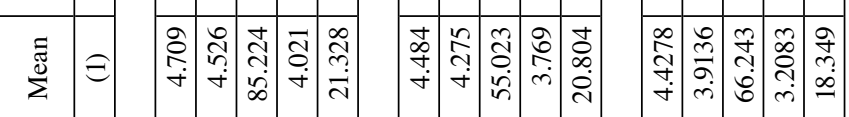

\begin{tabular}{|c|c|c|c|c|c|c|c|c|c|c|c|c|c|c|c|c|c|c|}
\hline $\begin{array}{l}\frac{0}{\pi} \\
\frac{\pi}{\tilde{\pi}} \\
\frac{\pi}{\nu}\end{array}$ & & $\sum_{2}^{1}$ & $\begin{array}{l}5 \\
z\end{array}$ & 齐 & 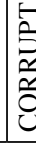 & $\frac{x}{4}$ & 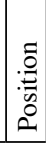 & $\sum_{\text {监 }}$ & \begin{tabular}{|l}
$\bar{y}$ \\
$\underline{z}$
\end{tabular} & $\begin{array}{l}\stackrel{a}{x} \\
\text { x }\end{array}$ & 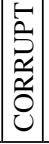 & $\underset{\forall}{x}$ & & $\sum_{\substack{n \\
2}}$ & 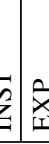 & 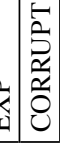 & $\frac{x}{\breve{s}}$ & ; \\
\hline
\end{tabular}




\begin{tabular}{|c|c|c|c|c|c|c|c|c|c|c|c|c|c|c|c|c|c|c|c|c|c|c|c|c|c|}
\hline & $\sum_{0}^{J}$ & $\widehat{\Xi}$ & $\begin{array}{c}\stackrel{*}{*} \\
\stackrel{m}{0} \\
\end{array}$ & $\begin{array}{l}\hat{b} \\
\stackrel{e}{e}\end{array}$ & $\mid$\begin{tabular}{c}
$*$ \\
\multirow{2}{*}{} \\
\multirow{2}{*}{} \\
$\stackrel{0}{0}$
\end{tabular} & $\stackrel{\widehat{\widehat{\imath}}}{\stackrel{e}{e}}$ & $\begin{array}{l}\stackrel{*}{\circ} \\
\stackrel{0}{\circ}\end{array}$ & $\begin{array}{l}\tilde{O} \\
\dot{e} \\
\dot{e}\end{array} \mid$ & $\left|\begin{array}{l}0 \\
0 \\
1 \\
1\end{array}\right|$ & $\stackrel{\widehat{c}}{\vec{e}}$ & $\begin{array}{c}0 \\
0 \\
0 \\
1\end{array}$ & త్ & $\mid$ & $\begin{array}{l}\text { đิ } \\
\stackrel{0}{\ominus}\end{array}$ & 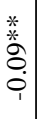 & $\begin{array}{l}\stackrel{f}{0} \\
\stackrel{0}{e}\end{array}$ & $\begin{array}{l}1 \\
0 \\
0 \\
1\end{array}$ & $\begin{array}{l}\tilde{2} \\
\stackrel{2}{e}\end{array}$ & \begin{tabular}{l|l}
8 \\
$\vdots$ \\
\\
\end{tabular} & \begin{tabular}{l|l}
$\tilde{\sigma}$ & $a$ \\
$\dot{e}$ & \\
$\dot{e}$ &
\end{tabular} & \begin{tabular}{ll|l}
0 \\
\\
& &
\end{tabular} & 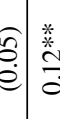 & 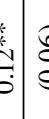 & & \\
\hline & $\sum_{j}^{\exists}$ & 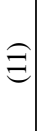 & 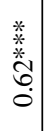 & 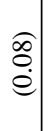 & 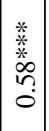 & 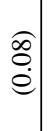 & 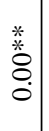 & $\begin{array}{l}\grave{\partial} \\
\dot{e} \\
\dot{e}\end{array}$ & 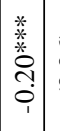 & $\begin{array}{l}\stackrel{\theta}{0} \\
\stackrel{e}{e}\end{array}$ & 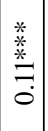 & $\mid \begin{array}{l}\widehat{\widehat{S}} \\
\dot{e} \\
\dot{e}\end{array}$ & & & & & & & & & & & & & \\
\hline & 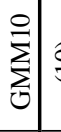 & 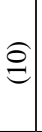 & 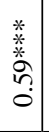 & $\begin{array}{l}\stackrel{f}{\Xi} \\
\stackrel{e}{e}\end{array}$ & $\mid$\begin{tabular}{c}
$*$ \\
\multirow{*}{*}{} \\
$\stackrel{*}{*}$ \\
$\stackrel{0}{\circ}$
\end{tabular} & 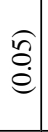 & 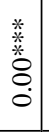 & $\begin{array}{c}\stackrel{\Xi}{8} \\
\dot{e}\end{array}$ & 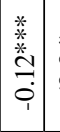 & $\begin{array}{l}\stackrel{f}{\Xi} \\
\stackrel{e}{e}\end{array}$ & 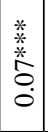 & $\widehat{\vec{b}}$ & & & & & & & & & & & & & \\
\hline & $\sum_{0}^{g}$ & 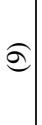 & 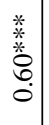 & $\begin{array}{c}\stackrel{f}{\Xi} \\
\stackrel{e}{e}\end{array}$ & $\mid$\begin{tabular}{c}
$*$ \\
$*$ \\
$*$ \\
\multirow{*}{*}{+} \\
$\dot{0}$
\end{tabular} & $\begin{array}{l}\widehat{o} \\
\stackrel{0}{e}\end{array}$ & 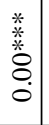 & $\mid \begin{array}{c}\stackrel{g}{b} \\
\dot{e}\end{array}$ & $\mid$\begin{tabular}{c}
$*$ \\
\multirow{*}{*}{} \\
$\stackrel{*}{\sim}$ \\
$\stackrel{\varphi}{\varphi}$ \\
1
\end{tabular} & $\begin{array}{l}\stackrel{f}{\Xi} \\
\stackrel{e}{e}\end{array}$ & $\begin{array}{l}* \\
* \\
* \\
\stackrel{*}{*} \\
\stackrel{0}{0} \\
0\end{array}$ & $\widehat{\widehat{a}}$ & & & & & & & & & & & & & \\
\hline ڤે & $\sum_{0}^{\infty}$ & $\widehat{\infty}$ & 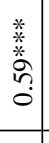 & $\begin{array}{l}\stackrel{f}{\leftrightarrows} \\
\stackrel{e}{e}\end{array}$ & $\mid$\begin{tabular}{c}
$*$ \\
\multirow{*}{*}{} \\
$\stackrel{2}{*}$ \\
$\stackrel{5}{0}$ \\
0
\end{tabular} & $\begin{array}{l}\overparen{8} \\
\stackrel{0}{e}\end{array}$ & 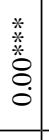 & $\begin{array}{l}\hat{\delta} \\
\dot{e}\end{array}$ & 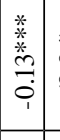 & $\begin{array}{l}\overparen{J} \\
\stackrel{0}{\varrho}\end{array}$ & 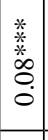 & $\widehat{\vec{\sigma}}$ & & & & & & & & & & & & & \\
\hline 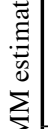 & $\sum_{\Xi}$ & $\varepsilon$ & 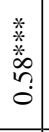 & $\stackrel{f}{\stackrel{f}{0}}$ & 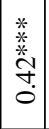 & $\begin{array}{l}0 \\
\stackrel{0}{\bullet} \\
\stackrel{\theta}{0}\end{array}$ & 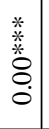 & $\begin{array}{l}\mathscr{g} \\
\dot{\theta} \\
\dot{e}\end{array}$ & 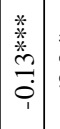 & 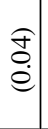 & 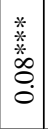 & $\widehat{\widehat{c}}$ & & & & & & & & & & & & & \\
\hline 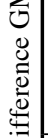 & $\sum_{0}^{\infty}$ & $\widehat{\sigma}$ & \begin{tabular}{c}
$*$ \\
$*$ \\
$*$ \\
\multirow{*}{*}{} \\
0 \\
0
\end{tabular} & $\begin{array}{l}\stackrel{f}{0} \\
\stackrel{e}{e}\end{array}$ & 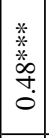 & $\begin{array}{l}\widehat{E} \\
\mathbf{0} \\
\stackrel{0}{0}\end{array}$ & 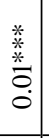 & $\begin{array}{l} \\
\grave{\Xi} \\
\dot{e}\end{array}$ & 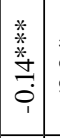 & $\stackrel{\overparen{\Xi}}{\stackrel{\Xi}{\varrho}}$ & $\begin{array}{l}* \\
* \\
* \\
\infty \\
\infty \\
0 \\
0\end{array}$ & $\widehat{\widehat{\sigma}}$ & & & & & & & & & & & & & \\
\hline & $\sum_{0}^{n}$ & $\sqrt{6}$ & 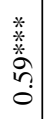 & $\begin{array}{l}\stackrel{f}{\Xi} \\
\stackrel{e}{e}\end{array}$ & 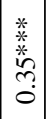 & $\begin{array}{l}\mathscr{0} \\
\stackrel{0}{e} \\
\stackrel{0}{2}\end{array}$ & 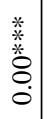 & $\begin{array}{l}\mathscr{\theta} \\
\dot{\theta} \\
\dot{e}\end{array}$ & 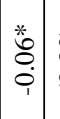 & 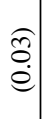 & 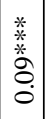 & $\widehat{\widehat{a}}$ & & & & & & & & & & & & & \\
\hline & $\sum_{j}^{+}$ & Ð & 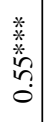 & $\begin{array}{c}\widehat{\hat{\sigma}} \\
\stackrel{e}{e}\end{array}$ & 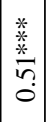 & 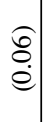 & $\begin{array}{l}\text { 蒡 } \\
\stackrel{*}{\circ} \\
\stackrel{0}{\circ}\end{array}$ & $\mid \begin{array}{l}\stackrel{\Xi}{0} \\
\dot{e}\end{array}$ & 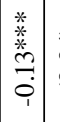 & $\begin{array}{l}f \\
\stackrel{f}{\dot{b}} \\
\stackrel{e}{e}\end{array}$ & 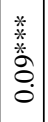 & $\widehat{\widehat{\sigma}}$ & & & & & & & & & & & & & \\
\hline & $\sum_{0}^{n}$ & (ิ) & 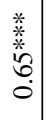 & ڤે̣ & 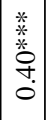 & $\begin{array}{l}0 \\
\stackrel{0}{0} \\
\stackrel{e}{0}\end{array}$ & 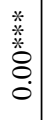 & $\begin{array}{l}\widehat{\Xi} \\
\dot{e}\end{array}$ & 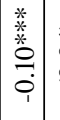 & $\begin{array}{l}\text { f } \\
\stackrel{0}{e} \\
\stackrel{e}{e}\end{array}$ & $\mid \begin{array}{c}* \\
* \\
* \\
* \\
0 \\
0 \\
\dot{0}\end{array}$ & $\widehat{\widehat{\vec{b}}}$ & & & & & & & & & & & & & \\
\hline & $\sum_{0}^{\mathcal{N}}$ & $\widehat{d}$ & 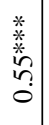 & $\begin{array}{l}\stackrel{f}{J} \\
\stackrel{e}{e}\end{array}$ & \begin{tabular}{l}
$*$ \\
\multirow{*}{*}{} \\
$\stackrel{*}{*}$ \\
$\dot{0}$
\end{tabular} & $\begin{array}{l}\widehat{\delta} \\
\stackrel{0}{e}\end{array}$ & 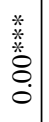 & $\begin{array}{c}\widehat{\Xi} \\
\dot{e} \\
\dot{e}\end{array}$ & 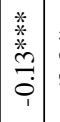 & $\begin{array}{c}\text { f } \\
\stackrel{\Xi}{e}\end{array}$ & 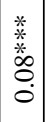 & $\widehat{\widehat{\sigma}}$ & & & & & & & & & & & & & \\
\hline & $\sum_{j}$ & $\Theta$ & $\begin{array}{l}\frac{*}{*} \\
\stackrel{*}{*} \\
\stackrel{m}{0} \\
ٌ\end{array}$ & 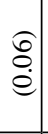 & 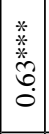 & $\frac{\mathfrak{n}}{e}$ & \begin{tabular}{l|}
$*$ \\
\multirow{*}{*}{} \\
$\stackrel{2}{0}$ \\
$\stackrel{0}{0}$
\end{tabular} & $\mid \begin{array}{l}\tilde{\partial} \\
\dot{e} \\
\dot{e}\end{array}$ & $\begin{array}{l}m \\
0 \\
0 \\
1\end{array} \mid$ & $\begin{array}{c}\hat{0} \\
\stackrel{0}{e}\end{array}$ & $\begin{array}{l}\stackrel{*}{*} \\
\stackrel{*}{*} \\
\stackrel{0}{0}\end{array}$ & बิ & 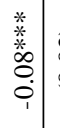 & ठิ & 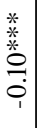 & శิ & 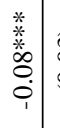 & $\stackrel{\overbrace{}}{\hat{0}}$ & 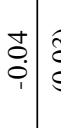 & 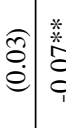 & 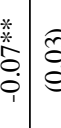 & 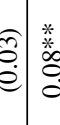 & | & $\frac{\widehat{c}}{2}$ & \\
\hline & 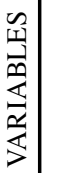 & & 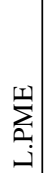 & & 侌 & & $\underset{\substack{x \\
-1}}{a}$ & & 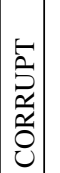 & & $\frac{x}{a}$ & & 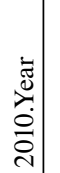 & & 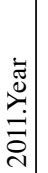 & & 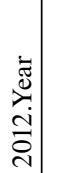 & & 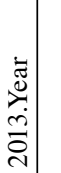 & 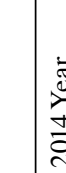 & 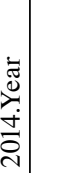 & 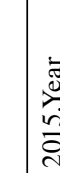 & 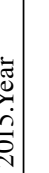 & & 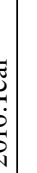 \\
\hline
\end{tabular}




\begin{tabular}{|c|c|c|c|c|c|c|c|c|c|c|c|c|c|c|c|c|c|c|c|c|c|c|c|}
\hline$\sum_{j}^{N}$ & $\stackrel{*}{\stackrel{*}{\sigma}}$ & 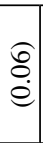 & \begin{tabular}{|c|}
$*$ \\
$\stackrel{*}{*}$ \\
$\stackrel{0}{0}$ \\
\multirow{2}{*}{}
\end{tabular} & $\begin{array}{l}\widehat{\sigma} \\
\dot{e}\end{array}$ & $\begin{array}{l}\infty \\
\vdots \\
0\end{array}$ & 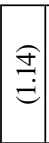 & $\begin{array}{l}\stackrel{8}{\infty} \\
\text { N }\end{array}$ & $\stackrel{\infty}{\sim}$ & 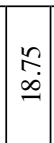 & 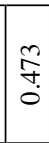 & $\stackrel{\infty}{\sim}$ & 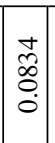 & मे & 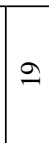 & 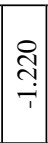 & 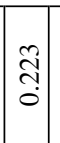 & $\overrightarrow{\vec{\lambda}}$ & 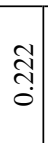 & $\mid \begin{array}{l}\overrightarrow{0} \\
+ \\
0 \\
1\end{array}$ & $\begin{array}{l}0 \\
\stackrel{n}{0} \\
0 \\
0\end{array}$ & 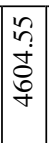 & \begin{tabular}{|l|} 
\\
\\
8 \\
\hdashline \\
\end{tabular} & \\
\hline$\sum_{j}^{\exists}$ & & & & & 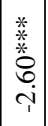 & 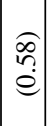 & $\begin{array}{l}\stackrel{8}{\sim} \\
\text { D. }\end{array}$ & $\stackrel{\infty}{\sim}$ & $\begin{array}{l}\overrightarrow{\tilde{n}} \\
\dot{\vec{\lambda}}\end{array}$ & ָ̃ & 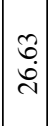 & $\underset{⿱}{ \pm}$ & $\approx$ & 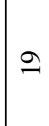 & $\mid \begin{array}{l}\overrightarrow{\hat{v}} \\
\vec{i}\end{array}$ & $\left|\begin{array}{l}\bar{\delta} \\
\dot{0}\end{array}\right|$ & $\mid \begin{array}{l}n \\
n \\
0 \\
0\end{array}$ & $\begin{array}{l}0 \\
n \\
0\end{array}$ & $\mid \begin{array}{c}0 \\
0 \\
0 \\
0 \\
1\end{array}$ & $\begin{array}{c}F \\
\tilde{n} \\
0\end{array}$ & & & \\
\hline$\sum_{0}^{0}$ & & & & & 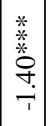 & $\begin{array}{l}\widehat{\alpha} \\
\tilde{0} \\
e \\
e\end{array}$ & $\underset{\sim}{\stackrel{D}{\sim}}$ & $\stackrel{\infty}{\sim}$ & 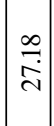 & 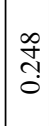 & $\stackrel{\infty}{\sim}$ & $\mid \begin{array}{c}0 \\
\stackrel{1}{0} \\
0\end{array}$ & $\grave{\curvearrowright}$ & $\ddot{\imath}$ & $\mid \begin{array}{l}\hat{\delta} \\
0 \\
\dot{r} \\
i\end{array}$ & $\left|\begin{array}{l}0 \\
\vdots \\
\vdots \\
0\end{array}\right|$ & 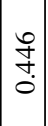 & $\begin{array}{l}n \\
\vdots \\
0 \\
0\end{array}$ & 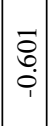 & 先 & & & \\
\hline$\sum_{j}^{0}$ & & & & & $\begin{array}{l}\stackrel{*}{*} \\
\stackrel{*}{*} \\
\stackrel{5}{*} \\
\stackrel{i}{i}\end{array}$ & $\begin{array}{l}0 \\
0 \\
e \\
e\end{array}$ & $\begin{array}{l}\stackrel{8}{\sim} \\
\text { d }\end{array}$ & $\stackrel{\infty}{\sim}$ & $\mid \begin{array}{l}\bar{\sigma} \\
\hat{i} \\
\hat{N}\end{array}$ & 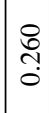 & $\stackrel{\infty}{\sim}$ & $\mid \begin{array}{c}0 \\
\\
0\end{array}$ & ते & $\tilde{\lambda}$ & \begin{tabular}{|l|l}
$\infty$ \\
0 \\
$\dot{0}$ \\
$\dot{r}$
\end{tabular} & $\left|\begin{array}{l}0 \\
\vdots \\
\vdots \\
0\end{array}\right|$ & 竎 & $\begin{array}{c}1 \\
\vdots \\
0 \\
0\end{array}$ & $\left|\begin{array}{l}n \\
0 \\
0 \\
0 \\
1 \\
1\end{array}\right|$ & กิ? & & & \\
\hline$\sum_{j}^{\infty}$ & & & & & $\begin{array}{c}\frac{*}{*} \\
\stackrel{*}{*} \\
\stackrel{+}{*}\end{array}$ & 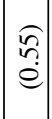 & $\underset{\sim}{\stackrel{D}{\sim}}$ & $\stackrel{\infty}{\sim}$ & 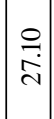 & $\bar{n}$ & $\stackrel{\infty}{\sim}$ & $\mid$\begin{tabular}{c}
0 \\
0 \\
\hdashline \\
0 \\
0
\end{tabular} & $\vec{m}$ & $\approx$ & 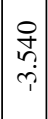 & $\left|\begin{array}{l|}8 \\
0 \\
0 \\
0\end{array}\right|$ & $\mid \begin{array}{l}0 \\
\stackrel{n}{0} \\
0 \\
0\end{array}$ & $\begin{array}{l}n \\
\hat{b} \\
0\end{array}$ & $\mid \begin{array}{c}0 \\
0 \\
0 \\
0 \\
1\end{array}$ & กิ & & & \\
\hline$\sum_{j}^{5}$ & & & & & $\frac{*}{\stackrel{*}{*}}$ & $\mid \begin{array}{c}\widehat{o} \\
\stackrel{n}{e} \\
e\end{array}$ & $\begin{array}{l}0 \\
\stackrel{\sim}{N}\end{array}$ & $\stackrel{\infty}{\sim}$ & 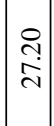 & $\stackrel{\tilde{n}}{f}$ & $\stackrel{\sim}{\sim}$ & $\underset{\nabla}{\overrightarrow{7}}$ & 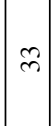 & $\hat{\imath}$ & 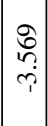 & $\left|\begin{array}{l}0 \\
\vdots \\
\vdots \\
0\end{array}\right|$ & స్ & 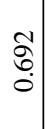 & $\begin{array}{l}\mathbb{Z} \\
0 \\
0 \\
i\end{array}$ & กี่ & & & \\
\hline$\sum_{0}^{\infty}$ & & & & & 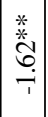 & $\mid \begin{array}{l}\mathscr{a} \\
0 \\
\dot{e}\end{array}$ & $\underset{\sim}{\stackrel{D}{\sim}}$ & $\stackrel{\infty}{\sim}$ & $\mid \begin{array}{l}\hat{\sigma} \\
\hat{i} \\
\hat{i}\end{array}$ & 告 & $\stackrel{\infty}{\sim}$ & $\mid \begin{array}{c}\infty \\
\tilde{n} \\
0\end{array}$ & $m$ & $\curvearrowright$ & $\mid \begin{array}{c}0 \\
0 \\
\vdots \\
\dot{n} \\
1\end{array}$ & $\left|\begin{array}{l}0 \\
\vdots \\
0 \\
0\end{array}\right|$ & $\mid \begin{array}{l}\tilde{0} \\
n \\
0 \\
0\end{array}$ & $\sqrt{n}$ & $\begin{array}{l}\overrightarrow{\widehat{\sigma}} \\
\dot{0} \\
\dot{1}\end{array}$ & $\begin{array}{l}+ \\
\tilde{o} \\
0\end{array}$ & & & \\
\hline$\sum_{0}^{n}$ & & & & & $\begin{array}{c}\stackrel{*}{*} \\
\stackrel{*}{*} \\
\stackrel{+}{*} \\
\rightarrow\end{array}$ & $\mid \begin{array}{l}0 \\
\dot{o} \\
\dot{e}\end{array}$ & $\begin{array}{l}\stackrel{\triangleright}{\sim} \\
\text { d }\end{array}$ & $\stackrel{\infty}{\sim}$ & $\mid \begin{array}{l}\infty \\
\dot{0} \\
\dot{\nu}\end{array}$ & 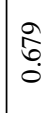 & $\stackrel{\infty}{\sim}$ & $\mid \begin{array}{l}\vec{\sigma} \\
\dot{0}\end{array}$ & $\hat{m}$ & $\bar{m}$ & $\mid \begin{array}{c}\tilde{z} \\
\tilde{n} \\
\tilde{r}\end{array}$ & $\left|\begin{array}{l}\bar{\sigma} \\
\vdots \\
0\end{array}\right|$ & 守 & 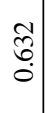 & $\mid \begin{array}{l}\overrightarrow{0} \\
n \\
? \\
1 \\
1\end{array}$ & $\begin{array}{l}\overrightarrow{0} \\
? \\
0\end{array}$ & & & \\
\hline$\sum_{0}^{J}$ & & & & & 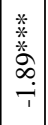 & $\begin{array}{c}\widehat{\tilde{n}} \\
\stackrel{?}{e}\end{array}$ & $\underset{\sim}{\mathbb{N}}$ & $\stackrel{\infty}{\sim}$ & 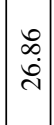 & 宅 & $\stackrel{\infty}{\sim}$ & $\begin{array}{c}\vec{\sigma} \\
0 \\
0\end{array}$ & $\hat{m}$ & $\bar{m}$ & $\begin{array}{l}\hat{\imath} \\
\hat{\imath} \\
\hat{i}\end{array}$ & $\left|\begin{array}{l}\bar{\sigma} \\
\vdots \\
\dot{0}\end{array}\right|$ & $\begin{array}{l}\hat{a} \\
0 \\
0\end{array}$ & \begin{tabular}{c}
0 \\
$\stackrel{0}{\infty}$ \\
\multirow{0}{*}{} \\
0
\end{tabular} & $\begin{array}{l}\overrightarrow{\widehat{\sigma}} \\
\dot{0} \\
1\end{array}$ & $\begin{array}{l}n \\
\tilde{n} \\
0\end{array}$ & & & $\begin{array}{l}v \\
v \\
* \\
\stackrel{0}{0} \\
0\end{array}$ \\
\hline$\sum_{0}^{m}$ & & & & & 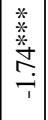 & $\begin{array}{l}\stackrel{f}{f} \\
\stackrel{e}{e}\end{array}$ & 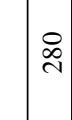 & $\stackrel{\infty}{\sim}$ & $\begin{array}{l}n \\
\stackrel{\sim}{\sim} \\
\end{array}$ & 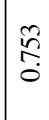 & $\stackrel{\infty}{\sim}$ & $\underset{⿱}{\stackrel{\Xi}{0}}$ & ले & $m$ & $\left|\begin{array}{c}\tilde{b} \\
0 \\
\dot{\gamma} \\
i\end{array}\right|$ & $\left|\begin{array}{l}0 \\
\vdots \\
\vdots \\
0\end{array}\right|$ & 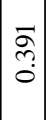 & $\begin{array}{l}0 \\
0 \\
0 \\
0\end{array}$ & 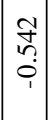 & $\begin{array}{l}0 \\
\infty \\
\vdots \\
0\end{array}$ & & & $\stackrel{*}{*} \dot{0}$ \\
\hline$\sum_{0}^{\mathbb{N}}$ & & & & & 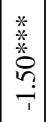 & $\mid \begin{array}{c}f \\
\stackrel{f}{e} \\
e\end{array}$ & $\underset{\sim}{\stackrel{D}{\sim}}$ & $\stackrel{\infty}{\sim}$ & $\mid \begin{array}{l}\hat{\sigma} \\
\hat{i} \\
\text { in }\end{array}$ & $\mid \begin{array}{c}2 \\
\infty \\
0 \\
0\end{array}$ & $\stackrel{\infty}{\sim}$ & 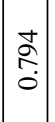 & $F$ & 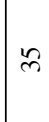 & $\mid \begin{array}{c}\hat{2} \\
\hat{\tilde{r}} \\
\end{array}$ & $\left|\begin{array}{l}\overline{8} \\
\dot{0}\end{array}\right|$ & $\mid \begin{array}{l}0 \\
0 \\
0 \\
0\end{array}$ & 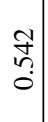 & $\begin{array}{l}\vec{f} \\
\stackrel{0}{0} \\
\dot{i}\end{array}$ & 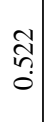 & & & 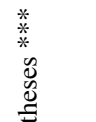 \\
\hline$\sum_{j}^{\overline{1}}$ & $\begin{array}{l}0 \\
\\
0\end{array}$ & $\begin{array}{l}\hat{f} \\
\stackrel{e}{e}\end{array}$ & $\mid \begin{array}{l}n \\
0 \\
0\end{array}$ & $\begin{array}{l}\stackrel{\Im}{t} \\
\dot{e}\end{array}$ & $\begin{array}{l}\text { ب̂. } \\
\stackrel{1}{1} \\
1\end{array}$ & $\widehat{\hat{\sigma}}$ & $\begin{array}{l}\stackrel{\infty}{\sim} \\
\sim\end{array}$ & $\stackrel{\infty}{\sim}$ & $\mid \begin{array}{l}0 \\
0 \\
0 \\
0\end{array}$ & ふ̊. & $\stackrel{\infty}{\sim}$ & $\mid \begin{array}{l}t \\
2 \\
0 \\
0\end{array}$ & in & 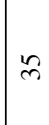 & $\mid \begin{array}{c}0 \\
⿱ \\
+ \\
i \\
i\end{array}$ & $\left|\begin{array}{l}0 \\
0 \\
0 \\
0\end{array}\right|$ & $\mid \begin{array}{l}n \\
2 \\
\stackrel{2}{0} \\
1\end{array}$ & 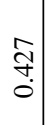 & $\mid \begin{array}{l}2 \\
0 \\
0 \\
0 \\
1\end{array}$ & $\begin{array}{c}\vec{\sigma} \\
\dot{0} \\
\dot{0}\end{array}$ & $\begin{array}{l}0 \\
\stackrel{0}{0} \\
\grave{0} \\
0 \\
0\end{array}$ & $\begin{array}{l}8 \\
0 \\
0 \\
0\end{array}$ & $\begin{array}{l}\overline{0} \\
\bar{\Xi} \\
. \\
心 \\
0\end{array}$ \\
\hline 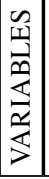 & 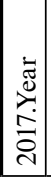 & & 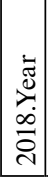 & & 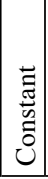 & & 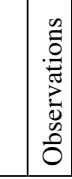 & $\mathrm{z}$ & $\left|\begin{array}{c}\mathcal{N} \\
\tilde{5} \\
\tilde{n} \\
\tilde{n}\end{array}\right|$ & . & 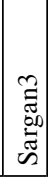 & a & 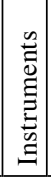 & 항 & $\left|\begin{array}{l}\widehat{\sigma} \\
\frac{a}{<}\end{array}\right|$ & $=$ & $\mid \begin{array}{l}\widehat{d} \\
\frac{a}{<}\end{array}$ & 2 & $\mid \begin{array}{l}\widehat{0} \\
\frac{2}{4}\end{array}$ & & 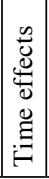 & $=$ & 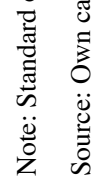 \\
\hline
\end{tabular}


Table 6 Static panel and LSDVC estimation

\begin{tabular}{|c|c|c|c|c|c|c|}
\hline & \multicolumn{3}{|c|}{ Static panel model } & \multicolumn{3}{|c|}{ LSDVC } \\
\hline & $\mathrm{RE}$ & $\mathrm{FE}$ & $\begin{array}{c}\text { First } \\
\text { differences }\end{array}$ & $\mathrm{AH}$ & $\mathrm{AB}$ & $\mathrm{BB}$ \\
\hline \multirow[t]{2}{*}{ L.PME } & - & - & - & $0.88^{* * * *}$ & $0.68^{* * *}$ & $1.25^{* * *}$ \\
\hline & & & & $(0.11)$ & $(0.06)$ & $(0.02)$ \\
\hline \multirow[t]{2}{*}{ INST } & $0.42^{* * *}$ & $0.40^{* * * *}$ & $0.55^{* * * *}$ & $0.42 * * *$ & 0.09 & 0.06 \\
\hline & $(0.15)$ & $(0.11)$ & $(0.06)$ & $(0.09)$ & $(0.06)$ & $(0.06)$ \\
\hline \multirow[t]{2}{*}{ EXP } & $0.00 * *$ & 0.00 & $-0.00 * *$ & 0.00 & 0.00 & -0.00 \\
\hline & $(0.00)$ & $(0.00)$ & $(0.00)$ & $(0.00)$ & $(0.00)$ & $(0.00)$ \\
\hline \multirow[t]{2}{*}{ CORRUPT } & 0.01 & 0.01 & $-0.10 * *$ & 0.02 & $0.07 * *$ & 0.08 ** \\
\hline & $(0.09)$ & $(0.07)$ & $(0.04)$ & $(0.05)$ & $(0.03)$ & $(0.04)$ \\
\hline \multirow[t]{2}{*}{ TAX } & 0.00 & 0.00 & 0.00 & $0.02 * * *$ & $0.02^{* * * *}$ & $0.02^{* * * *}$ \\
\hline & $(0.00)$ & $(0.01)$ & $(0.00)$ & $(0.01)$ & $(0.01)$ & $(0.01)$ \\
\hline \multirow[t]{2}{*}{ Intercept } & $2.57 * * *$ & $2.59 * * *$ & $0.02 * * *$ & - & - & - \\
\hline & $(0.41)$ & $(0.23)$ & $(0.01)$ & & & \\
\hline Observations & 308 & 308 & 280 & 280 & 280 & 280 \\
\hline Id & 28 & 28 & 28 & 28 & 28 & 28 \\
\hline
\end{tabular}

Note: Standard errors in parentheses $* * * \mathrm{p}<0.01, * * \mathrm{p}<0.05, * \mathrm{p}<0.1$. The variables are differenced in the first differences model.

Source: Own calculations 


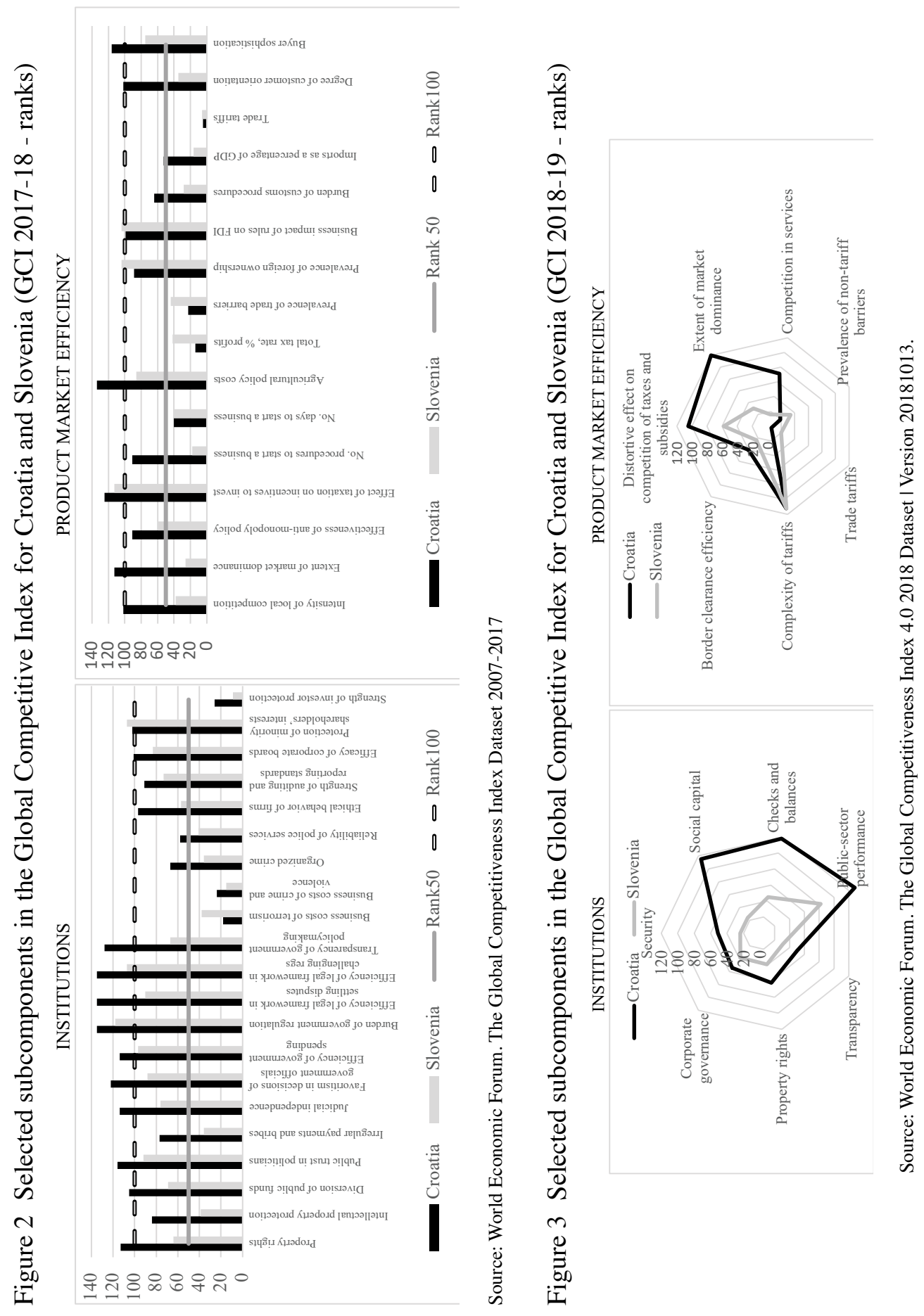




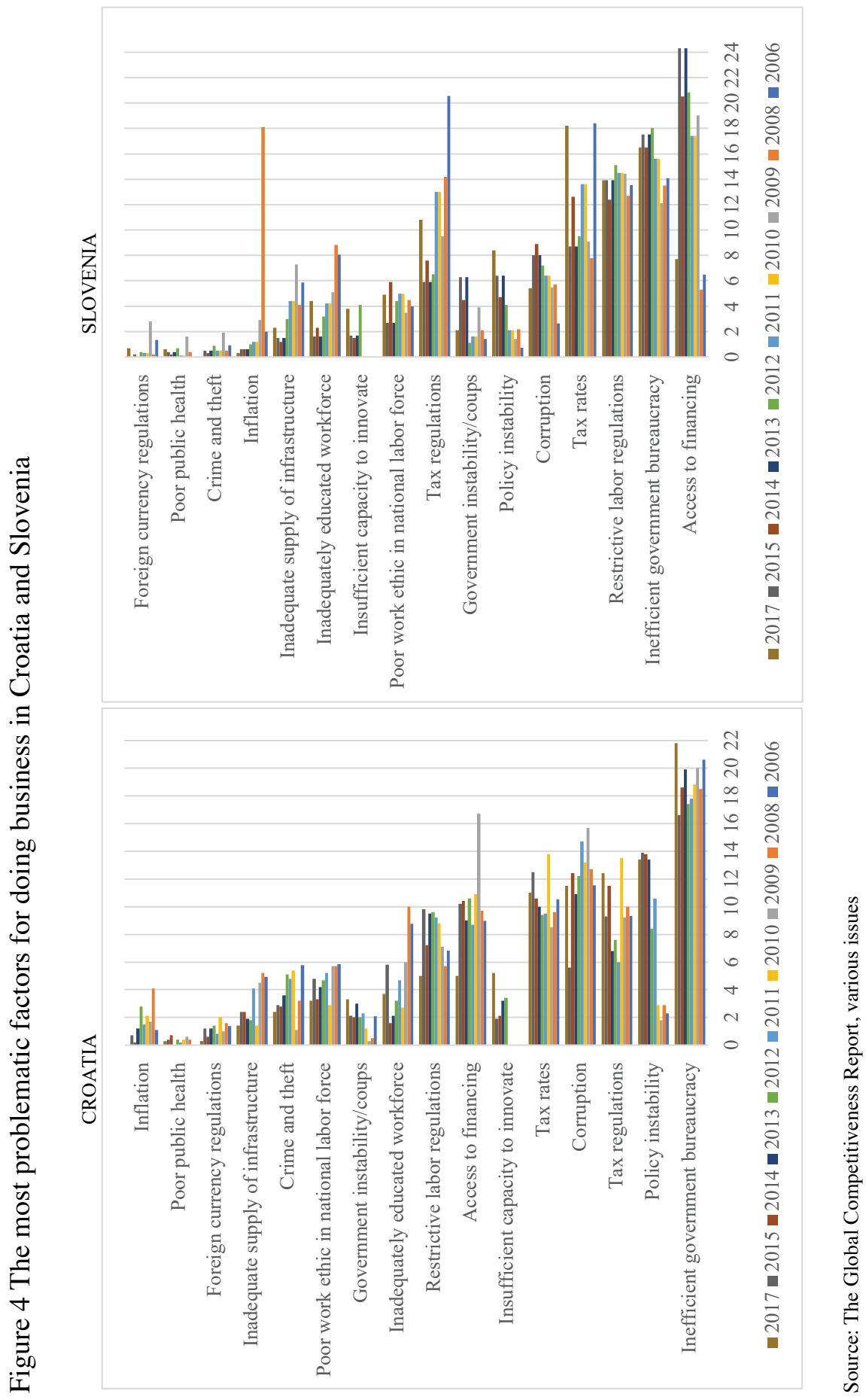




\section{NOTES}

1 Why small countries are highlighted in this hypothesis is explained later in this paper.

2 Since institutions are not created overnight, the length of a state's independence can be an important determinant of the quality of institutions. In our sample only two countries gained independence in the 19th century by separating from the Ottoman Empire, and that all others were created after 1918 by the collapse of the Russian Empire and the Austro-Hungarian Monarchy. But the independence of most of the countries analyzed was limited after World War II due to dependence on the Soviet Union.

3 According to the criteria of Bräutigam and Woolcock (2001), the small countries of our sample (new EU) are: Cyprus, Croatia, Estonia, Ireland, Latvia, Lithuania, Malta and Slovenia. Mediterranean countries are Cyprus, Croatia, France, Greece, Italy, Malta, Portugal, Slovenia and Spain. Post-socialist countries are Bulgaria, Croatia, Czech Republic, Estonia, Hungary, Latvia, Lithuania, Poland, Romania, Slovak Republic and Slovenia.

4 The Levin, Lin and Chu (2002) test (hence LLC) showed that only TAX is not stationary. Some regressions include TAX in the first differences but none in the top 11 best regressions.

5 The number of instruments could also be reduced by satisfying Kiviet (2020) recommendations for the Sargan test and the autocorrelation test if some regression variables are considered strictly exogenous.

6 Table 6 in the Appendix shows an estimate of the static panel model (random effects RE, fixed effects $\mathrm{FE}$, and first differences FD) where the significance of the INST variable is confirmed, but the FD estimator has similar results as the difference GMM.

7 This problem is not eliminated if the CORRUPT variable is strictly exogenous, but then the parameter of the INST variable is significantly increased. Multicollinearity is eliminated only by excluding the INST variable from the model. Although the values of Sargan statistics, autocorrelation test, and number of instruments are acceptable, such action is not justified by information criteria. Furthermore, according to the results so far, the INST variable was one of the most important in all equations.

8 Table 6 in the Appendix also contains LSDVC estimator values assuming that all regression variables were exogenous. Consistent estimators (AH, $\mathrm{AB}$ or $\mathrm{BB}$ ) are used in LSDV estimator correction. Depending on this, three LSDVC estimator values can be obtained that lead to different conclusions. The closest to the presented results from Table 5 is the first LSDVC (based on AH estimator) where all parameters are positive, but (with lag of the dependent variable) only INST and TAX are significant. Compared to Table 5, the gamma parameter is higher in all LSDVC estimators, but the assumption of strictly exogenous regressors is unlikely to be correct.

\section{REFERENCES}

Adkins, L. C., Moomaw, R. L., \& Savvides, A. (2002). Institutions, freedom, and technical efficiency. Southern economic journal, 69(1), 92-108. DOI: 10.2307/1061558

Agostino, M., Di Tommaso, M. R., Nifo, A., Rubini, L., \& Trivieri, F. (2020). Institutional quality and firms' productivity in European regions. Regional Studies, 54(9), 1275-1288. DOI: 10.1080/00343404.2020.1712689

Allegra, E., Forni, M., Grillo, M., \& Magnani, L. (2004). Antitrust Policy and National Growth: Some Evidence from Italy. Giornale degli Economisti e Annali di Economia, 63(1), 69-86.

Anderson, T. W., \& Hsiao, C. (1981). Estimation of dynamic models with error components. Journal of the American Statistical Association, 76(375), 589-606. DOI:10.2307/2287517 
Anderson, T. W., \& Hsiao, C. (1983). Formulation and estimation of dynamic models using panel data. Journal of Econometrics, 18(1), 570-606. DOI: 10.1016/0304-4076(82)90095-1

Andrews, D. W., \& Lu, B. (2001). Consistent model and moment selection procedures for GMM estimation with application to dynamic panel data models. Journal of Econometrics, 101(1), 123-164. DOI:10.1016/S0304-4076(00)00077-4

Arellano, M., \& Bond, S. (1991). Some Tests of specification for Panel Data: Monte Carlo Evidence and Application to Employment Equations. Review of Economic Studies, 58(2), 277-297. DOI: $10.2307 / 2297968$

Arellano, M., \& Bover, O. (1995). Another look at the instrumental variable estimation of errorcomponents models. Journal of Econometrics, 68(1), 29-51. DOI: 10.1016/03044076(94)01642-D

Arnone, M., \& Scalise, D. (2005). Macroeconomic Effects of Deregulation in Goods Market with Heterogeneous Firms. Macroeconomics - University Library of Munich.

Blanchard, O., \& Giavazzi, F. (2003). Macroeconomic Effects of Regulation and Deregulation in Goods and Labor Markets. Quarterly Journal of Economics, 118(3), 879-907. DOI: $10.1162 / 00335530360698450$

Blundell, R., \& Bond, S. (1998). Initial conditions and movement restrictions in dynamic panel data models. Journal of econometrics, 87(1), str. 115-143.

Bouis, R., Duval, R., \& Eugster, J. (2016). Product Market Deregulation and Growth: New CountryIndustry-Level Evidence. IMF Working Papers 16(114). DOI: 10.5089/9781484385029.001

Bourlés, R., Cette, G., Lopez, J., Mairesse, J., \& Nicoletti, G. (2013). Do Product Market Regulations in Upstream Sectors Curb Productivity Growth? Panel Data Evidence for OECD Countries. The Review of Economics and Statistics, 95(5), 1750-1768. DOI: 10.3386/w16520

Bräutigam, D., \& Woolcock, M. (2001). Small states in a global economy: The role of institutions in managing vulnerability and opportunity in small developing countries (No. 2001/37). WIDER Discussion Paper.

Bruno, G. S. (2005). Approximating the bias of the LSDV estimator for dynamic unbalanced panel data models. Economics Letters, 87(3), 361-366. DOI: 10.1016/j.econlet.2005.01.005

Buddelmeyer, H., Jensen, P., Oğuzoğlu, U., \& Webster, E. (2008). Fixed Effects Bias in Panel Data Estimators. IZA Dicussion Paper No. 3487, 1-7.

Cacciatore, M., Fiori, G., \& Ghironi, F. (2015). Market Deregulation and Optimal Monetary Policy in a Monetary Union. Journal of International Economics, 120-137. DOI: 10.3386/w19025

Chacar, A. S., Newburry, W., \& Vissa, B. (2010). Bringing institutions into performance persistence research: Exploring the impact of product, financial, and labor market institutions. Journal of International Business Studies, 41(7), 1119-1140.

Chanda, A., \& Dalgaard, C. J. (2008). Dual economies and international total factor productivity differences: Channelling the impact from institutions, trade, and geography. Economica, 75(300), 629-661. DOI: 10.1111/j.1468-0335.2007.00673.x

Correa-López, M., \& Doménech, R. (2014). Does anti-competitive service sector regulation harm exporters? Evidence from manufacturing firms in Spain. BBVA Research WP, 14, 13

de Pina-Cabral, J. (1989). The Mediterranean as a category of regional comparison: a critical view. Current Anthropology, 30(3), 399-406. DOI: /10.1086/203758

Égert, B. (2016). Regulation, institutions, and productivity: new macroeconomic evidence from OECD countries. American Economic Review, 106(5), 109-13. DOI: 10.1257/aer.p20161026

Franičević, V., \& Bićanić, I. (2007). EU Accession and Croatia's Two Economic Goals: Modern Economic Growth and Modern Regulated Capitalism. Journal of Southeast European and Black Sea Studies, 7(4), 637-663. DOI:10.1080/14683850701726104

Gal, P. N., \& Hijzen, A. (2016). The Short-term impact of product market reforms. IMF Working Papers 2016(116). DOI: 10.5089/9781475516852.001 
Gilmore, D. D. (Ed.). (1987). Honor and Shame and the Unity of the Mediterranean (Vol. 22). Washington, DC: American Anthropological Association.

Gilson, R. J., \& Kraakman, R. (2003). The mechanisms of market efficiency twenty years later: The hindsight bias. Journal of Corporation Law, 28(4), 715-742.

Gouveia, A. F., Santos, S., \& Gonçalves, I. (2017). The impact of structural reforms on productivity: The role of the distance to the technological frontier. OECD Productivity working papers May 2017 No.8.

Ivanković, Ž. (2017). The Political Economy of Crony Capitalism: A Case Study of the Collapse of the Largest Croatian Conglomerate. Croatian Political Science Review, 54(4), 40-60.

Judson, R., \& Owen, A. (1999). Estimating dynamic panel data models: a guide for macroeconomists. Economic letters, 65(1), 9-15. DOI: 10.1016/S0165-1765(99)00130-5

Kaufmann, Daniel, Aart Kraay and Massimo Mastruzzi (2010). "The Worldwide Governance Indicators: Methodology and Analytical Issues". World Bank Policy Research Working Paper No. 5430 (http://papers.ssrn.com/sol3/papers.cfm?abstract_id=1682130)

Kiviet, J. F. (1995). On bias, inconsistency and efficiency of various estimators in dynamic panel data models. Journal of Econometrics, 68(1), 53-78. DOI: 10.1016/0304-4076(94)01643-E

Kiviet, J. F. (2020). Microeconometric dynamic panel data methods: Model specification and selection issues. Econometrics and Statistics, 13(1), 16-45. DOI:10.1016/j.ecosta.2019.08.003

Kotarski, K., \& Petak, Z. (2019). Croatia's Post-communist Transition Experience: The Paradox of Initial Advantage Turning into a Middle-Income Trap. In Z. Petak, \& K. Kotarski(ed.), Policy Making at the European Periphery. Palgrave Macmillan, 1-25.

Kripfganz, S. (9. September 2019). Generalized method of moments estimation of linear dynamic panel data models. Downloaded 28.03.2021 from Stata Conferences: https://www.stata.com/ meeting/uk19/slides/uk19_kripfganz.pdf

Levin, A., Lin, C.-F., \& Chu, C.-S. J. (2002). Unit root tests in panel data: asymptotic and finite-sample properties. Journal of Econometrics, 108(1), 1-24. DOI:10.1016/S0304-4076(01)00098-7

Mosquera, P. M. R., Manstead, A. S., \& Fischer, A. H. (2002). Honor in the Mediterranean and northern Europe. Journal of cross-cultural psychology, 33(1), 16-36. DOI: $10.1177 / 0022022102033001002$

North, D. (1990). Institutions, Institutional Change and Economic Performance. Cambridge University Press. DOI: $10.1017 /$ cbo9780511808678

Pattnaik, C. \& Choe, S. (2007). Do institutional quality and institutional distance impact subsidiary performance? Academy of Management Proceedings, 2007 (1), 1-6. DOI: 10.5465/ ambpp.2007.26508371

Rodríguez-Pose, A., Ganau, R., Maslauskaite, K., \& Brezzi, M. (2020). Credit constraints, labor productivity, and the role of regional institutions: Evidence from manufacturing firms in Europe. Journal of Regional Science. 1-30. DOI: 10.1111/jors.12514

Rodrik, D., Subramanian, A., \& Trebbi, F. (2004). Institutions Rule: The Primacy of Institutions Over Geography and Integration in Economic Development. Journal of Economic Growth, 9(2), 131-165. DOI: 10.1023/b:joeg.0000031425.72248.85

Rogić Dumančić,L., Bogdan, Ž., \& Raguž Krištić, I. (2021). Institutions and Product Market Efficiency in the European Union with Emphasis on Croatia. Accepted for the Conference Region, Entrepreneurship, Development - Faculty of Economics in Osijek.

Roodman, D. (2009). Practitioners' corner: A Note on the Theme of Too Many Instruments. Oxford Bulletin of Economics and Statistics, 71(1), 135-158. DOI:10.1111/j.1468-0084.2008.00542.x

Sargan, D. J. (1958). The estimation of economic relationships using instrumental variables. Econometrica, 26(3), 393-415. DOI:10.2307/1907619

Schwab(ed.), K. (2017). The Global Competitiveness Report 2017-2018. Geneva: World Economic Forum. 
Schwab(ed.), K. (2018). The Global Competitiveness Report 2018-2019. Geneva: World Economic Forum.

Škrabić-Perić, B. (2019). Do the most frequently used dynamic panel data estimators have the best performance in a small sample? A Monte Carlo comparison? Operational Research Review, 10(1), 45-54. DOI: 10.17535/crorr.2019.0005

Veenendaal, W. (2019). How Smallness Fosters Clientelism: A Case Study of Malta. Political Studies, 67(4), str. 1034-1052. DOI: 10.1177/0032321719828275

World Bank (various years). Worldwide Governance Indicators project. World Bank Development Research Group. http://info.worldbank.org/governance/wgi/\#home. (Accessed on: March 19th, 2019)

Weil, D. N. (2009). Economic Growth (3rd ed.). Pearson. 